\title{
GUTIÉRREZ DE SANTA CLARA, ESCRITOR MEXICANO
}

\section{I}

¿Por qué no ocupa Pedro Gutiérrez de Santa Clara el lugar que le corresponde en las letras de la Nueva España? La contestación es obvia. El autor de la Historia de las guerras civiles del Peri" ${ }^{1}$ ha sido totalmente abandonado al Perú como "testigo número i" de la guerra pizarrista de $\mathbf{1 5 4 4 - 4 8}$. A pesar del carácter acentuadamente literario de su seudocrónica - "grandes frescos con el movimiento, el colorido y la desenvoltura vital de las escenas de Tintoreto", según ponderaba el llorado Raúl Porras Barrenechea ${ }^{2}$-, se admitió (por el mismo historiador) "que es acaso autobiografía" del autor "porque debió ver muchas de las escenas que narra" y "carece por completo de nota alguna subjetiva y personal". Vino, pues, a ser considerada aquella obra copiosa (más que monumental) como película documental de unos años de historia peruana, no como fruto de una original vocación de escritor de un mexicano de fines del siglo xvi.

$Y$ sin embargo... Hace doce años empecé a dudar de que fuese el autor testigo ocular de "muchas de las escenas que narra". Expliqué en mi cátedra del Collège de France, y después en Symposium ${ }^{3}$, el privilegiado lugar que, gracias a su usurpada fama, conquistó Gutiérrez de Santa Clara en la historiografía de un episodio de la vida de Bartolomé de las Casas: la trágica aventura de los campesinos desembarcados por "el clérigo" en la costa de Cumaná. En las páginas que les dedica nuestro seudocronista, la principal ventaja que lleva a los cronistas consiste en prosificar unas amenas octavas de las Elegias de ilustres varones de Indias de Juan de Castellanos (1589),

1 Remitiremos a ella (Historia...) por la única edición existente, en seis tomos, que con este título publicó Manuel Serrano y Sanz (Madrid, 19o4-1929, tomos 2, 3, 4, 10, 20 y 21 de la "Colección de Libros y Documentos referentes a la Historia de América" de la Librería de Victoriano Suárez). No creo que merezca salvarse el término pedante de Quinquenarios que, en el incipit del manuscrito, se le ocurrió al autor aplicar a los cinco libros de su obra.

2 Raúl Porras Barreneciena, "Pedro Gutiérrez de Santa Clara, cronista mexicano de la conquista del Perú (1521-1603)", $R H A, 1946$, núm. 21 , p. 1.

${ }^{3} A C F, 1951$, pp. 254-255; "Cheminement d'une légende", $S, 6$ (1952), 1-21 (traducción española en $L T, 1,1953$, núm. 4, 41-63). 
con su lujo de nombres y apellidos rústicos y algunas ocurrencias que fácilmente pasarían por "desenvoltura vital" del plagiario. Pero estas escenas de 1521-22, era evidente que no podía Gutiérrez de Santa Clara haberlas "vivido". Desde hace cinco años, estudié detenidamente y expuse en tres cursos consecutivos $(1959,1960 \text { y } 1961)^{4}$ su técnica literaria de seudotestigo en las diversas partes de su obra. Un verdadero testigo ocular no puede caracterizarse per la omnipresencia, no puede diferenciarse de los otros "cronistas" por una cantidad mayor de color y movimiento derrochada imparcialmente sobre la mayor parte de las escenas narradas por ellos. No pudo "vivir" a la vez, para pintarlas después con igual "vida", cosas ocurridas casi al mismo tiempo, unas en Quito, otras en el Cuzco en la primavera de $1547^{5}$. Es más: el auténtico testigo - pensemos en las horas de Waterloo vividas por Fabrice en La Chartreuse de Parme- no ve el acontecimiento con sus rasgos "históricos" precisamente porque lo vive desde su rincón. Lo que conoce personalmente el héroe stendhaliano son instantes ahistóricos de la batalla. Gutiérrez de Santa Clara pinta, como si los viera, a los protagonistas en acción en cada episodio decisivo, presentándolos al lector tales como pasaron a la historia, ellos y el episodio. Lo cual da a pensar que sus pinturas son fruto, no de una experiencia personal, forzosamente limitada, sino de una técnica de reanimación imaginativa, fácil de aplicar a un cúmulo de conocimientos librescos. Hace más de 40 años relacioné la ubicuidad del seudotestigo Gabriel Araceli, en Zaragoza, con las completísimas fuentes históricas que explotaba Pérez Galdós sobre los dos sitios de la ciudad en $1808.1809^{6}$.

Desde luego Galdós, en sus Episodios nacionales, no pretende hacer sino novela histórica de divulgación. Gutiérrez de Santa Clara, en sus "episodios coloniales" escritos unos $5^{\circ}$ años después de los sucesos, cometió la superchería literaria de presentarse él como actor de la guerra pizarrista, sobre la cual estaba exhaustivamente documentado. Pero lo hizo sin nitidez, sin honradez, y no llegó a "ubicarse" de manera convincente. Poquísimas veces en su narración (no llegan a media docena) escribe como "testigo", en primera persona, unas cosas anecdóticas que lo situarían en el campo pizarrista: si diéramos crédito a estas manifestaciones del yo del narrador, estaría con Francisco de Carvajal en La Plata en el otoño de 1546.

Vale la pena recordar este cuento en primera persona (Historia, t. 3, p. 308), cuyo crédito se fundó sin duda en el de su principal fuente literaria: en la tardía autoridad del Palentino, muy dado a recoger, ampliar o inventar el folklore de los acontecimientos, veinte

4 ACF de los mismos años.

5 Como la muerte de Pedro Puelles en Quito y la entrada de Diego Centeno en el Cuzco.

6 "Les sources historiques de Zaragoza", BHi, 23 (1921), 129-141. 
años después. Amenizó, pues, el Palentino la dramática historia de Morales de Abad o Amburt, a quien sus compañeros llamaron el Resucitado ${ }^{7}$ porque, herido y condenado a garrote por Carvajal, había sido mal estrangulado, y finalmente perdonado por el jefe pizarrista; pero, implicado unos meses después en la conjuración de La Plata (víspera de San Miguel de 1546), huyó, fue preso, y llegó a la muerte definitiva. La sal de la doble peripecia, en Diego Fernández de Palencia, consiste en los diálogos sarcásticos de Carvajal con su víctima. Gutiérrez de Santa Clara, sin desperdiciar nada de estos elementos, añade al cuento una nueva dimensión, imaginando que Morales el Resucitado, un día, en La Plata, le contó a él, Gutiérrez, unos detalles inauditos sobre... ;su aventura de ultratumba transitoria! Morales se convierte en un beato, casi fraile, persuadido de que ha comparecido ante la Virgen y ha sido restituido a la vida terrestre para hacer penitencia, en premio de su devoción a Nuestra Señora y a las Once mil Vírgenes. Pero descubre la hilaza el ironista mexicano cuando abre el capítulo del milagro con un preámbulo insólito:

Estoy perplejo y muy dudoso en contar una cosa que sucedió en esta tierra, que cierto soy muy enemigo de relatar cosas de admiración a todas gentes, porque no saben cómo son ni cómo pasaron.

Las palabras que subrayamos sugieren que el escritor conocía, a más del Palentino (y, tal vez, de la Resurrección de Celestina de Feliciano de Silva), la tradición de los cuentistas de lo inverosímil. Recordaba casi seguramente este preámbulo que hace Pero Mexía antes de referir la historia increíble de un hombre misteriosamente desaparecido, que, al reaparecer, cuenta su visita al infierno, y no tarda en morir: "Como ya creo que otra vez tengo dicho, consejo es de sabios que las cosas de admiración no las debe hombre contar...". Y efectivamente había dicho, antes de contar la patraña del "pece Nicolao": "Muchos sabios aconsejan que no cuente hombre las cosas de admiración, porque por la mayor parte se duda de la verdad dellas..." También recordaría Gutiérrez - ya que la prosifica- la copla proverbial aludida por el autor de la Silva:

7 Diego Fernández, natural de Palencia, Primera parte de la historia del Perú, ed. Lucas de Torre, Madrid, 1914, t. 2, pp. 56 y 68. El Palentino llama al "resucitado" Morales de Abad, natural de Cuenca; Cieza de León (Guerra de Quito, en $N B A E$, t. ${ }_{15}$, pp. $288 b$ y $289 a$ ), menos inexactamente, Morales de Ambur. Pero la forma correcta del nombre la da Francisco de Carvajal en persona en una carta (de Chuquisaca, 17 nov. 1546) a Gonzalo Pizarro: "un Mathías de Morales de Ambún que yo mandé desahorcar la noche de la batalla". Habiendo Morales huido de La Plata al ser descubierta la conjuración, añade Carvajal que lo mandó perseguir, "y traýdo aquí [a Chuquisaca] lo hizieron quartos" (Papeles Pizarro-Gasca de la Henry E. Huntington Library de San Marino, Calif.; II, fol. $55^{6} \mathrm{r}^{\circ}$ ). Era fácil, dado el personaje del "desahorcado", ir inventando las circunstancias del cuento del Resucitado. 
las cosas de admiración

no las digas ni las cuentes, que no saben todas gentes cómo son ${ }^{8}$.

Pero ¿cómo podría bastar una reelaboración tan claramente literaria del cuento de Morales el Resucitado para convencernos de que Gutiérrez de Santa Clara conversó con el tal Morales en La Plata poco antes del día de San Miguel de 1546 ?

Si el seudocronista quisiese dar consistencia histórica, y no gracia literaria, al privilegio de testigo ocular que reivindica, le bastaría resumir, aunque fuese escuetamente, en uno de sus prólogos, las principales etapas de su participación en los acontecimientos de 1544-48. Pero en su "Prohemio", p. 17, se contenta con decir en términos generales que estuvo "presente a casi todas estas cosas" y las vio "por vista de ojos", y luego añade que fue primero "soldado del capitán Pablo de Meneses, que entonces servía al virrey Blasco Núñez Vela" (es decir, en 1544), y en cuanto a la época siguiente, que hasta la venida del Presidente Pedro de la Gasea (es decir, hasta 1546-47) "y aun hasta la prisión del tirano y de sus sequaces" (es decir, hasta 1548), supo muchas cosas "por muchas nuevas ciertas y cartas que embiaron al capitán Lorenço de Aldana, que era theniente y justicia mayor de Gonzalo Piçarro en Lima, a quien servi en esto comedio de Secretario". Ahora bien, Aldana salió de Lima para Panamá (donde se reintegró al campo leal, poniéndose a las órdenes de Gasea) en octubre de 1546 , después del día de San Miguel (29 de septiembre). ¿Qué fue, después, de nuestro "testigo" hasta la derrota pizarrista? Se nos escurre entre los dedos. Es abundantísima la documentación coetánea sobre la guerra de $1544-48$; se catalogan ínfimos actores de ella, ya como castigados, ya como perdonados después de la victoria de Gasca en Xaquixaguana. Llegan a 2,133 los personajes mencionados por los otros cronistas y los informantes coetáneos, en el fichero provisional que me formó mi colaborador Robert Klein, basándose sólo en las historias y relaciones conocidas de la guerra

8 PEDro MExía, Silva de varia lección, 2a parte, cap. 23, ed. Biblióflos Españoles, Madrid, 1933, t. 1, p. 391, y 1 $1^{\text {a }}$ parte, 23, ibid., p. 141. Antonio DE Torquemada, Jardin de flores curiosas (ed. Biblióf. Esp., Madrid, 1953, p. 11) cita los versos atribuyéndolos al Marqués de Santillana, y confirma la fuente Américo Castro (El pensamiento de Cervantes, Madrid, 1925, p. 391) citando la edición Amador de los Ríos de los Proverbios del Marqués (p. 52). Se habían convertido en tópico de los narradores de historias extraordinarias. Baste recordar un pasaje del Viaje de Turquia de Andrés LAGuna (mal atribuido a Cris. tóbal de Villalón por Serrano y Sanz, quien en su edición de Autobiografias y memorias, $N B A E$, t. 2, p. 1 $3^{b}$, imprime el "refrán" como prosa) y el más famoso, de Cervantes (Persiles, III, cap. 16), que humorísticamente recuerda "aquellos antiguos versos castellanos" a propósito de "cosas y casos" que "por la raridad con que acontecen, passan plaça de apócrifos y no son tenidos por tan verdaderos como lo son". 
pizarrista y en la documentación peruana publicada en las colecciones de documentos inéditos. Este fichero puede enriquecerse con muchos nombres más, gracias al fndice del catálogo de la Harkness Collection de la Biblioteca del Congreso de Washington". También salen no pocos del olvido gracias al examen de los Papeles PizarroGasca conservados en la Henry E. Huntington Library de San Marino (California). ¿Cómo no aparece en ninguna parte nuestro seudocronista, si fue soldado bastante destacado para ser nada menos que secretario del teniente del caudillo rebelde en Lima? Serrano y Sanz empezó a publicar sus Guerras civiles del Perú en 1904: acabó (con el t. 6) en 1929. Durante el cuarto de siglo que medió entre sus dos prólogos editoriales, buscó tenazmente el erudito aragonés alguna huella del soldado o del secretario Pedro Gutiérrez de Santa Clara en el Archivo de Indias, y no la halló.

Gran alborozo debió experimentar el benemérito investigador peruano Rafael Loredo cuando descubrió el alarde que de su ejército hizo Carvajal"10 el "demonio de los Andes", en el momento de entrar en La Plata, es decir, poco antes de que Gutiérrez de Santa Clara o su doble literario "escuchase" el cuento fantástico de "Morales el Resucitado" de boca del propio Morales, "estando yo y él en la villa de La Plata. .. assentados en un poyo en casa de Juan de Orellana". Pero entre los 15 o soldados y oficiales reseñados en el alarde, sólo figura un Pedro Gutiérrez: se trata de Pero Gutiérrez de Zafra ${ }^{11}$. Loredo, persuadido de que en alguna manera andaba por allí nuestro autor en 1546 , tuvo que acudir a la hipótesis de que el presunto testigo ocular seguía al ejército pizarrista, no ya como soldado, sino como mercader (art. cit., pp. 270-271, nota 85). ¿No era "memoria de mercader" aquella retentiva tan fiel como para "recordar", medio siglo después, los precios y calidades de las mercancías, los colores varios de las sedas, damascos y tafetanes que vestían los jefes o con que se hacían las banderas? Veremos que nuestro narrador bien pudo tener imaginación de mercader.

Es preciso haber cotejado la totalidad de la obra de Gutiérrez de Santa Clara con la mayor parte de sus fuentes evidentes o pro-

9 The Harkness Collection in the Library of Congress, t. 1, Washington, 1932 (Calendar of Spanish manuscripts concerning Peru, I53I-I65I); t. 12, 1936 (Documents from early Peru. The Pizarros and the Almagros, 1531-1578).

10 Rafael LoRedo lo publicó con extenso comentario en "Alardes y derramas", Revista de Historia, Órgano del Instituto Histórico del Perú, t. 14 (Lima, 1941), entrega 3, pp. 292-296.

11 A quien nombra una vez el seudocronista (t. 3, p. 365) copiando al Palentino (ed. cit., t. 2, p. 67). También menciona Cieza de Lé́n (Guerra de Quito, ed. cit., p. $287 b$ ) a "Pedro Gutiérrez de Zafra contador", nombrado por Carvajal entre otros oficiales. Expresa el capitán Carvajal el alto concepto en que lo tenía, a pesar de haber seguido a la fuerza el estandarte de Centeno, en una carta inédita (del 11 de diciembre de 1546) dirigida a Gonzalo Pizarro desde Chuquisaca (Papeles Pizarro-Gasca, II, fol. 545). 
bables para apreciar a fondo la socarronería de su técnica. Ya Serrano y Sanz, en su último prólogo (1929), advertía algo que no había dicho en el primero (1904). Sin poner en tela de juicio la sinceridad del seudo-actor de la guerra pizarrista, tomando por buena la afirmación de los "borradores" que trajo de allá12, consideró su obra como "comenzada en la juventud", pero admitió que había utilizado "a más de recuerdos propios", narraciones ajenas, y aun noticias de libros impresos (Historia, t. 6, pp. ix-x), como las conocidas historias de Francisco López de Gómara, Agustín de Zárate y Diego Fernández el Palentino. Utilización bastante ceñida a las fuentes, según confirma Robert B. Knox. Podemos añadir algunas más. La exactitud general de la topografía y de la toponimia peruana de Gutiérrez de Santa Clara, elemento que contribuyó seguramente a hacer creer que recorrió el Perú, deja de impresionarnos cuando manejamos un fichero de los topónimos mencionados y situados por Pedro Cieza de León en la Primera parte de la historia del Perú (Sevilla, 1554). A este libro debe su bastante certera geografía ${ }^{13}$. Otras fuentes seguras de Pedro Gutiérrez en punto a libros impresos, son, para lo tocante al Perú prehispánico, el apéndice de la Segunda parte del Palentino ${ }^{14}$ y la Historia natural y moral de las Indias del padre Acosta. También utilizó, para dar "originalidad" a su versión del descubrimiento de América, un "best-seller" prohibido por la Inquisición, la Historia pontifical y católica de Gonzalo de Illescas ( $2^{\mathrm{a}}$ parte ${ }^{15}$.

Vista la libertad con que imagina pormenores, al bordar sobre noticias impresas, tratándose de acontecimientos que no pudo conocer personalmente, si advertimos además el ningún rigor de las indicaciones con que acreditó su escurridiza presencia en el Perú de $1544-48$, resulta más prudente la total incredulidad acerca de dicha presencia. Es más plausible la hipótesis de que la obra se escribió en el último decenio del siglo xvi, sin otra base que una abundante documentación, impresa e inédita. La credulidad que despistó a Serrano y Sanz y a otros historiadores en su apreciación de Gutiérrez

12 Historia, t. 1, p. 9 (Epístola al virrey Marqués de Montes Claros): “...sacándolas de mis borradores que traxe de allá".

13 A la misma fuente acudió con evidencia el propio Inca Garcilaso de la Vega al escribir en la vejez sobre su patria, de la cual habia salido a los 20 años sin haberla recorrido toda como Cieza.

14 Sevilla, 1571, fols. 125-130. Esta Segunda parte de la historia del Perú de Diego Fernández el Palentino no se ha reimpreso.

15 Libro cuyas primeras ediciones se han hecho raras de puro manejadas, y también por haber sufrido la prohibición inquisitorial. Puede ser que Gutiérrez de Santa Clara manejase una edición de Valladolid ${ }_{15} 67$ de la Segunda parte, que he mandado buscar sin éxito en numerosas bibliotecas españolas y extranjeras. La más antigua que he visto es la de Salamanca, 1574. L. PFandu, "Gonzalo de Illescas" en $S p F$, t. 3, p. 54, duda sin razón convincente de los datos de Llorente, Hist. crit. de l'Inquisition, Paris, 1818 , t. 1, pp. $475-476$, acerca de la edición recogida de 1567 . 
de Santa Clara no se justifica mejor que la que reinó en torno al Viaje de Turquia, otro libro inédito sacado a luz por Serrano y Sanz en 1904 como "autobiografía" y testimonio ocular sobre las cosas de Turquía en $1552-56$. Todo arranca, en uno y otro caso, de la superchería del prólogo. Pero el Viaje es anónimo, y sólo mediante una hipótesis plausible como la atribución al Doctor Laguna podemos situar la obra en la literatura de mediados del siglo xvI, entender su intención solapada de novela ingeniosa y documentada, y fechar su elaboración. Entonces resulta verosímil que el autor utiliza, hacia 1557 , además de libros impresos, una fuente entonces inédita como la primera relación de la embajada de Busbecq $(\mathbf{1 5 5 5})^{16}$.

Es más huidiza y enigmática la técnica del seudotestigo de la Guerra pizarrista, que tendría sus motivos para engañar, pero no los tenía para refugiarse en el anónimo. No contento con poner su nombre y apellido al final de cada uno de sus cinco libros, imitó torpemente la firma en acróstico puesta por Fernando de Rojas al frente de la Celestina, empezando cada octava con una letra de su nombre y apellido y revelando al fin su naturaleza de "MExicano". En esta desaliñada composición, sólo una de las 26 octavas (la que empieza por la $\mathbf{Y}$ de GUTYERREz) alude a la situación de testigo del autor (t. 6, p. 317):

Yo estuve en muchas cosas presente como hombre testigo de vista;

vide a leales passar por la cruel lista, morir d'estocadas así fieramente, de que se admiraba toda la gente; en fin morian a Dios invocando, el nombre del Rey siempre invocando, y así morían por él varonilmente.

Lástima que ni una sola vez, al contar una de estas escenas de crueldad, haya dicho el narrador: "yo la presencié".

Cotejadas las Guerras civiles del Perú con sus fuentes conocidas o probables, revela esta obra su deuda respecto de no pocos documentos inéditos: el capítulo dedicado a Las Casas (lib. I, cap. 2) tiene como base una relación biográfica bastante bien informada, pero que no pudo ser traída del Perú hacia $154^{8}$, pues llega hasta la extrema senectud del Obispo de Chiapa, y la interpola nuestro autor, como vimos, a base de unas octavas de la Elegias de Castellanos (1589). Para la parte mexicana de su Historia utiliza Gutiérrez, junto con López de Gómara, la Historia de los franciscanos de la Nueva España por fray Jerónimo de Mendieta, aún manuscrita entonces. En la mayor parte de su obra, dedicada a la guerra de $1544-48$, acude,

16 Cf. M. Bataillon, Le Docteur Laguna auteur du "Voyage en Turquie", Paris, 1958, pp. 70-79 (y BHi, 58, 1956, 149-157). 
además de las obras impresas por Gómara, Zárate y el Palentino, a informes inéditos que en parte coinciden con las fuentes aprovechadas por Cieza en la Guerra de Quito. Una de sus fuentes casi seguras es la relación de don Alonso de Montemayor, que Oviedo recogió, abreviándola, en el libro 49 (cap. 10) de su Historia general y natural de las Indias (parte que permaneció inédita hasta el siglo xıx). Ésta es tal vez la dosis de realidad que se esconde bajo la ficción de los "borradores traídos de allá" por el narrador: una relación y otros documentos traídos del Perú no por Gutiérrez de Santa Clara, sino por otro -u otros. Es casi seguro que el seudo-testigo manejó listas de secuaces de Pizarro como las que nos permiten hoy notar coincidencias de la onomástica de Gutiérrez con nombres de pizarristas oscuros (y comprobar que no se conoció ningún Pedro Gutiérrez de Santa Clara entre ellos), algún alarde de la tropa de Carvajal, alguna lista de los sancionados de 1548 . De tales fuentes parece haber tomado el escritor elementos para apellidar a bastantes figurillas que metió en su detalladísima historia, cambiando con frecuencia los nombres de pila, ya adrede, ya por mala lectura de grafías abreviadas. No debe extrañarnos el que un escritor de México, entre 1590 y 1600 , utilizara historias manuscritas y documentos inéditos sobre episodios del primer siglo de la conquista. Lo mismo que Pedro Gutiérrez de Santa Clara hace su paisano Baltasar Dorantes de Carranza, el cual, más que utilizar sus fuentes, las plagia (sin mencionarlas) ${ }^{17}$.

Baste recalcar aquí dos rasgos de la desenvuelta técnica que le sirvió para asentar su fama de testigo presencial. Uno es la ocultación de sus fuentes. A diferencia del Inca Garcilaso, que tampoco se abstiene de inventar detalles con ingenio de cuentista, pero se goza en citar y discutir las autoridades para hacer resaltar la originalidad de su propia versión, Gutiérrez de Santa Clara no menciona jamás ninguna de sus fuentes históricas impresas o inéditas. En cambio, procura despistar aludiendo a relaciones imaginarias, una de Francisco Maldonado, indicada, en el sospechosísimo Prohemio ${ }^{18}$, como

17 Ernesto de LA Torre Villar, "Baltasar Dorantes de Carranza y la Sumaria relación”, en Estudios de historiografia de la Nueva España, El Colegio de México, 1945, pp. $215^{-217}$.

18 Historia, t. 1, p. 17. La fórmula "hasta donde dize: de cómo Gonçalo Piçarro se adereçó para yr a la cibdad de Lima", para señalar el fin de los "borradores" de Francisco Maldonado sobre el principio de la sublevación, recuerda curiosamente la de Rojas, "hasta el segundo aucto donde dize Herma. nos mios, etc.", para indicar dónde acaba la obra del "antiguo auctor" de la Celestina. Así como es dudosa la existencia de tal supuesta fuente de los capítulos 1-14, es evidente la deuda de éstos respecto de Zárate y del Palentino. La idea de esta superchería pudo ser sugerida a Gutiérrez de Santa Clara por el hecho de que Francisco Maldonado, uno de los principales pizarristas, y cuñado, por cierto, del conocido relator de la Audiencia de México, Hernando de Herrera (cf. infra, nota 23), fue escogido por Gonzalo Pizarro para ir a de- 
fuente de los capítulos anteriores al cap. 15 de su libro I, invención tan poco verosímil como la existencia de los borradores de Francisco de Carvajal encontrados "entre su ropa", después de la derrota, y de los cuales el seudocronista pretende extractar un tratado del oficio del Maestre de campo que agrega a su obra ${ }^{19}$. También menciona Gutiérrez de Santa Clara otra relación manuscrita, en verso, "de un Juan Bautista de Escobar natural de las Riparias de Génova ${ }^{20}$ a quien nuestro seudocronista hace secretario del pirata Bachicao y cantor de sus hazañas.

Este caso ilustra ya el segundo rasgo fundamental de la socarronería con que procede. Consiste en dar nombre, apellido (y naturaleza muchas veces) a un sinfín de comparsas, camareros, botilleres, pajes, secretarios, criados, huéspedes de los personajes principales, haciendo, según se dijo de Balzac, "competencia al estado-civil". El impersonal y fugaz "mensajero" que, según el Palentino (libro I, cap. 38), manda Bachicao a Gonzalo Pizarro desde Manta, cuando pretende ser "Almirante de la Mar", cobra novelesca existencia al hacerse secretario y poeta de cámara del pirata, y al adquirir apellido español con patria genovesa. Lo notable es que otros dos "Juan Bautista Ginovés" aparecen en Gutiérrez de Santa Clara (t. 5, p. 246; t. 6, p. 166), uno muerto en una acción contra el pizarrista Pedro de Bustincia a principios de 1548 , otro condenado a galeras el mismo año, después de Xaquixaguana: y en la lista oficial de sancionados de $1548-50$ figura un individuo de ese nombre, condenado al destierro $^{21}$. ¿Nos convenceremos por eso de que Gutiérrez de Santa Clara conoció un elogio poético de Bachicao por un genovés llamado Juan Bautista de Escobar?

fender en la Corte la causa de la rebelión. Pero no se halla ninguna mención de un relato suyo en la abundante documentación que se conserva.

19 Historia, t. 5, p. 254. La idea de este apéndice es poco menos ingenua que la de otro dedicado a la manera peruana de hacer puentes colgantes, e ilustrado con un dibujo torpe y absurdo. Otro documento alegado por nuestro autor, y de existencia archidudosa, es un memorial sobre gastos de guerra "que tenía Pedro del Águila, secretario que fue del tirano" (t. 4, p. 283). Halló, no el memorial, sino al personaje, en algún documento sobre sanciones de 1548 . Habla el presidente Gasea (25 sept. 1548 , Co.Do.In., t. 49, p. 402) de "Pero Núnez del Águila, natural de Sevilla y secretario de Gonzalo Pizarro y su secuaz, el cual fue condenado a galeras". Cf. Col. de doc. inéd. del Archivo de Indias $[=$ D.I.I.], t. 2o, p. 502, "Pedro Núñez".

20 Historia, t. 2, p. 103. Cf. en las pp. 79, 88, 89 y 152 otras menciones de este personaje imaginario, repetidas para remachar el clavo. Excusado es decir que en la docena de cartas auténticas de Bachicao que se conservan, todas ellas de este episodio, varias escritas desde Manta, y alguna con mención del mensa. jero del pirata, no aparece el seudosecretario-mensajero-cronista insistentemente mencionado por Gutiérrez de Santa Clara.

${ }^{21}$ D.I.I., t. 20, p. 48 . Ibid., p. 540, un Bautista Ginovés condenado a muerte, contumaz. 
En una de las pocas páginas ${ }^{22}$ en que el narrador se pone en escena (una borrachera nocturna de jefes en casa de Carvajal en el otoño de 1544) puebla el tablado con comparsas, y no con figurantes anónimos: no contento con "el secretario Juan de Bustillo y el camarero Luis de Almao", personajes conocidos, introduce un "Alonso Martín Granado, botiller mayor" de Pizarro, mencionado sólo por él. Ahora bien, un "Alonso Martín" a secas aparece como piquero de Carvajal en el alarde publicado por Loredo (p. 295), y otro -o el mismo- figura en la lista de los sancionados de $154^{8-50}$ como natural de Nueva España (p. 494) y condenado al destierro. ¿Nos convenceremos por eso de que la "casa" de Gonzalo Pizarro, no bien designado como gobernador por los Oidores de Lima, comprendía un "botiller mayor", y de que la mención de un Alonso Martín Granado como "oficial" de la corte pizarrista abona la veracidad autobiográfica de la escena? No dejemos de advertir también que Gutiérrez de Santa Clara, en una lista de pizarristas que se pasan a Aldana en 1547, incluye a un "Alonso Martín Granado" (t. 4, p. 409). ¿Sería el "botiller mayor"? Baste saber que, con una constancia notable, la técnica de nuestro autor para remachar la existencia y personalidad de un comparsa introducido por él (siempre a la sombra de un personaje conocido) consiste en mencionarlo a lo menos dos veces, una de paso, otra con un papel anecdótico más o menos curioso.

Pero habiendo Gutiérrez de Santa Clara añadido con tal método unos 260 personajes, conocidos de él solo, y unos 45 con nombres de pila cambiados, a los 2133 que tenemos fichados a base de documentación fidedigna, ¿no era de esperar que se divirtiese en inventar a uno o varios "Pedros" más o menos relacionados con él, o con su yo de narrador? Parece que lo hizo efectivamente. Preguntábamos cómo pudo escabullirse un Pedro Gutiérrez de Santa Clara de estas "guerras más que civiles" sin dejar rastro, después de desempeñar un papel en el campo rebelde hasta 1546 por lo menos, y quedar vivo para contarlas. También se le ocurriría la misma dificultad al socarrón seudocronista... Es dramática para el campo pizarrista la peripecia en que el caudillo se aleja de Lima en el otoño de 1547 y le abandonan poco a poco sus tropas, mientras canturrea el "demonio de los Andes":

Estos mis cabellicos, madre,

dos a dos se los lleva el aire.

Marcha Pizarro de Lima "a la Nasca, cincuenta leguas de la ciudad de los Reyes, con sólo 200 hombres, porque los demás se le habían huido", según dice escuetamente el Palentino (lib. II, cap. 65, p. 307).

22 Historia, t. 2, p. 327. Esta evocación viene fuera del lugar cronológico que le correspondería en el relato. 
Pero este seco resumen lo amplía profusamente Gutiérrez de Santa Glara con su conocido don de "vida", detallando las etapas con arreglo a la topografía que le suministraba Cieza, y nombrando a no pocos soldados que uno a uno o dos a dos huyen al campo leal. Despedida privilegiada es la de un "Pedro" mexicano, que se va en la primera ocasión, la que se le brinda en Pachacamac. Allí dirige Gonzalo Pizarro una plática a sus soldados conforme a las buenas tradiciones de la historia militar - y de la historiografía renacentista-, avisándoles que pueden marcharse ahora los que no quieran serle fieles; pero que se vayan en el acto, porque después los traidores serán castigados sin piedad. Desde luego "todos a una boz dixeron que le querían seguir hasta la muerte"...

Ecepto Pedro del Golfo, vezino de la cibdad de México, en la Nueva España, que era piquero del capitán Hernando Bachicao, pidió licencia a Gonçalo Piçarro para boluerse a la cibdad y él se la dio, aunque con gran pesar... ${ }^{23}$

${ }_{23}$ Historia, t. 4, p. 418 . Siendo invención evidente la anécdota, creí primero que lo era también el apellido del héroe. Hasta que tropecé en los Papeles Pizarro-Gasca (I, fol. $117 \mathrm{v}^{\mathbf{0}}$, carta del relator de la Audiencia de México Hernando de Herrera a Gonzalo Pizarro, México, 12 de junio de 1546) con un "Pedro del Golfo" que llevó al Perú (o a Panamá) una provisión de la Audien. cia de México para el pago de un suministro de "unos negros y otras cosas" hecho por Andrés Núñez a Pizarro o a los pizarristas. Está documentada la actividad de Pedro del Golfo, ya "estante" alli en 1528, luego vecino de Tenuxtitlán-México, como tratante él también en caballos, mulas... y negros, en 1536 (A. Millares Carlo y J. I. Mantecón, fndice y extractos de los protocolos del Archivo de Notarias de México, D. F., El Colegio de México, 1946, t. 1, p. 342, núm. 1641; t. 2, pp. 68-69, núms. 2019 y 2020). Pudo conocerle nuestro seudocronista en su juventud, y recordar que durante la guerra pizarrista viajó al Perú... o a Panamá. Hacemos esta salvedad porque el istmo era el lugar de contratación normal entre la Nueva España y el Perú. En la carta del relator Hernando de Herrera se cita a otra persona estante "en esas partes", un tal Blas de Cisneros, como anteriormente encargado de cobrar la misma deuda de Andrés Núñez (o del relator-capitalista con el cual colaboraba en sus negocios: cf. Millares y Mantecón, op. cit., t. 2, p. 84, núms. 2077-78; p. 129, núm. 23o8; p. 176, núms. 2497-98; p. 177 , núm. 2502; p. 183, núm. 2529). Ahora bien, en una relación inédita de las hazañas de Bachicao en Panamá vemos a un "Zisneros" entre los propietarios de "naos cargadas para el Perú" que fueron víctimas de extorsiones del famoso pirata (doc. del 20 de marzo de 1545, Arch. Gen. de Indias, Patronato ${ }_{185}$, ramo 38 , in fine). Cieza, Guerra de Quito, ed. cit., p. $120 a$, menciona un navio venido de la Nueva España y capturado por el pirata. El propio Gutiérrez de Santa Clara (Historia, t. 2, pp. 78-79), poco antes de contar cómo Bachicao soltó un navio propiedad del Virrey de la Nueva España "por ser de quien era", habla de los mercaderes despojados y definitivamente arruinados por Bachicao: "que yo conoscí a dos dellos que murieron en la cárcel miserablemente" sin poder pagar sus deudas. ¿Los conocería en México, como al mismo Pedro del Golfo? De manera general, le gusta al seudocronista relacionar con su mundo novohispano a algunos de los personajes imaginados por él. Así sucede con "un montañés que se llamava Pedro de Praves, valiente y animoso" soldado de Carvajal (que por cierto 
Tan exorbitante resulta esta "licencia" hurtada al terror pizarrista, que Francisco de Carvajal y Bachicao, que marchaban a la retaguardia, castigan al "licenciado" con quitarle violentamente el caballo ensillado y enfrenado y dejarle en calzas y jubón. Puede Pedro dar gracias a Dios de haber llegado a Lima "a pie, como gentilhombre”. ¿Quién creerá que se alistó entre los sublevados del Perú el conocido mercader de México Pedro del Golfo y que salvó su vida y su lealtad al Rey gracias a un arranque retórico del caudillo rebelde?

En una etapa subsiguiente, la "del Guarco, repartimiento de Pedro Martín de Cecilia, donde antiguamente estuvo una gran fortaleza", huyen a medianoche, entre unos go soldados, Gabriel de Rojas y su sobrino Gómez de Rojas, "Lope Martín Portugués y Pedro Gutiérrez"24. De todos los personajes nombrados aquí por

no figura en el alarde de su ejército) a quien presta un papel bastante dramático entre los "descuidados" de la retaguardia después de la batalla de Pocona (t. 3, pp. 290-292 y 294-295). En el epilogo de su Historia lo mencionará el mestizo mexicano entre los pizarristas condenados en 1548 a ser "desterrados a Nueva España" (t. 6, p. 165). Lo cierto es que la lista de los sancionados comprende un "García de Praves, natural de Castro Urdíales", condenado en "cien azotes e desterrado destos Reynos perpetuamente para España, al remo en galera toda su vida e perdimiento de bienes" (D.I.I., t. 20, p. 514). Le haría gracia a nuestro autor conmutarle la pena de las "galeras de España" en destierro a la Nueva España (lugar de exilio de otros castigados: ibid., pp. 487, $\left.5^{\circ} 3,5^{\circ}, 510,519\right)$ al mismo tiempo que forjaba nuevo nombre de pila y nuevo destino a este montañés. - Robert Klein me señala otro caso posible de imposición de nombre mexicano como los de Pedro del Golfo y del licenciado Delgadillo (infra, nota 25). Es el del "tratante de carneros" castigado por Francisco de Carvajal, personaje anónimo en el Palentino (ed. cit., t. 2, p. 6o), cuya página correspondiente plagia nuestro autor (Historia, t. 3, pp. 301-304), llamando al tratante "Álvaro Nieto". Un capitán del mismo nombre y apellido forma en 1559 una compañía en Puebla de los Ángeles para ir a la conquista de la Florida con el general don Tristán de Luna y Arellano (Cartas de Indias, Madrid, 1877 , pp. 272 y 811 ).

24 Historia, t. 4, p. 435 . Así como el seudocronista se apodera del nombre de un verdadero paisano suyo para darlo al soldado Pedro del Golfo, pudo apoderarse aquí del nombre de un verdadero homónimo suyo pizarrista, cuya existencia descubriría en la documentación inédita que manejaba. En carta de Vaca de Castro a Gonzalo Pizarro (Guamanga, 2 sept. 1542: Papeles PizarroGasca, II, fol. $656 \mathbf{v}^{\circ}$ ) anuncia el Gobernador a Gonzalo, recién regresado de su expedición de la Canela, que le manda "perdón de todo" en lo del negocio de Pedro Gutiérrez, "pues tuvo tan buen intercesor". Después, en 1544 , menciona Cieza de León (Guerra de Quito, p. 64a) a un Pedro Gutiérrez entre los limeños que apoyan a los Oidores contra el Virrey. Tal vez sea distinto de Pedro Gutiérrez de Zafra, pero idéntico con Pedro Gutiérrez Altamirano, a quien el mismo Cieza (p. 263a) cita como hombre de confianza del capitán Carvajal, enviado por éste a Hayohayo después de la batalla de Pocona. En fin, en carta de Hacari, del 19 de septiembre de 1547 (Papeles Pizarro-Gasca, I, fol. 4), escribe Gonzalo de Morales a Gonzalo Pizarro dándole cuenta que deciden alejarse del puerto de este tambo "Pero Gutiérrez, Hernán Bueno y Araya y Pero López" y él, sin esperar más al navio que aguardaban, por temer una 
nuestro autor, el último, el homónimo, es el único desconocido de las fuentes fidedignas que mencionan pizarristas pasados entonces a la causa real. Por si esta superchería no bastase, el seudocronista, al final de su capítulo sobre la victoria de Gasea, recapitula "las dignidades" y "los letrados" que sirvieron en esta guerra a Su Majestad, y da a continuación una lista de letrados que estaban "de la parte del tirano" (t. 6, p. 117):

los licenciados Diego Vázquez de Cepeda, Antonio Pacheco, Cristóbal Sánchez Delgadillo, el doctor Juan Ortiz, Pedro Gutiérrez, y los bachilleres Juan Vélez de Guevara y Nuño de Castro, con otros muchos letrados...

Llama la atención el único "letrado" sin grado -Pedro Gutiérrez-, metido por su homónimo Pedro Gutiérrez de Santa Clara entre otros de conocida o dudosa existencia ${ }^{25}$.

sorpresa de los centenistas. Desde este mismo tambo de Hacari había escrito Gonzalo Pizarro el 8 de agosto a Diego Centeno procurando atraerle a su causa (Co.Do.In., t. 49, p. 161). Este Pero Gutiérrez, a diferencia del que nos presenta el seudocronista, no había abandonado el ejército de Gonzalo Pizarro antes de llegar éste al valle de Nazca (8-10 de agosto de 1547; cf. Papeles Pizarro Gasca, I, fol. 9). De los compañeros mencionados con él, Gonzalo de Morales, Pero López y Araya fueron fieles hasta el fin, pues recibieron pena de muerte los dos primeros (el segundo, contumaz) y de galeras el tercero (D.I.I., t. 20 , pp. 526, 539, 496). Es posible que los otros dos, Hernán Bueno y Pero Gutiérrez, hayan pasado al campo del presidente Gasca antes de Xaquixaguana. Lo mismo puede decirse de Damián de la Vandera que, mencionado como soldado de Carvajal en la misma carta de Gonzalo de Morales, no figura en listas de sancionados de 1548, y más tarde, en 1572 , había de ser corregidor en Potosí y Charcas (D.I.I., t. 8, p. 290). A este Damián de la Vandera le atribuye Gutiérrez de Santa Clara un curioso papel anecdótico en la época de Pocona (Hist., t. 3, pp. 257, 258, 260, 287, 288, 290-295, 299-301), en unión de un tal "Francisco Rodríguez Matamoros", cuyo nombre y papel forjó a base del Palentino y de documentos inéditos. Después (t. 4, p. 249) lo vuelve a mentar hábilmente con motivo del suplicio de Matamoros. Pero no figura Damián en el alarde del ejército de Carvajal en la etapa de la Plata (otoño de 1546) en que el seudocronista supone que anduvo con Carvajal.

${ }^{25}$ Si no plantea problema el oidor Vázquez de Cepeda, si el licenciado Antonio Pacheco puede identificarse hipotéticamente con un licenciado Pacheco que de Arequipa salió a unirse con Centeno en 1547, el "doctor Juan Ortiz" bien pudiera ser una descarada contaminación de Juan Ortiz de Zárate, que ocupaba entonces un cargo de teniente de gobernador en Santa Marta, con un Juan Ortiz "tambor" del ejército de Carvajal. Y el "licenciado Cristóbal Sánchez Delgadillo" ¿será idéntico con el "licenciado Cristóbal Sánchez" médico del capitán Carvajal, a quien Pedro Gutiérrez de Santa Clara pone repetidamente en escena con motivo de la enfermedad del demonio de los Andes en Andahuilas (t. 4, pp. 254-262)? Al imponer segundo apellido a este personaje, el escritor pudo echar mano una vez más de sus recuerdos de mocedad. Pocos meses después de morir el padre de Pedro Gutiérrez se alude en un documento de México a las casas que "labraba el licenciado Delgadillo" (Mrllares y MaNTECón, op. cit., t. 2, p. 178). Se trata casi con seguridad del tristemente famoso oidor licenciado Diego Delgadillo, con el cual tuvo algunos conflictos el obispo 
En vista de todo esto, no creo que sea arbitraria la sospecha de que, con la mención del soldado mexicano Pedro del Golfo y las dos menciones de "Pedro Gutiérrez" (una vez como "letrado"), Gutiérrez de Santa Clara quiso objetivar irónicamente dos soluciones del problema que inevitablemente se plantearía a su conciencia de "componedor", como se plantea al lector suspicaz: ¿cómo salió del ejército pizarrista el narrador, presunto testigo presencial, primero soldado, luego secretario, que tan informado se muestra de todo lo que pasaba en el campo de Gonzalo Pizarro y del capitán Carvajal? Siga el lector crédulo, si quiere, creyendo que el lujo de color y movimiento y el derroche de nombres propios ignorados de la documentación coetánea bastan para probar la calidad de testigo presencial. Mientras no se descubra un documento del siglo xvi que atestigüe la presencia de nuestro autor en el Perú entre 1544 y 1548 , no es hipercrítica, sino prudente, y también más fecunda para el investigador crítico, la hipótesis de que los cinco libros de las Guerras civiles del Perú son un ingenioso éxito de historiografía imaginativa, fundado en abundante documentación. No descartemos toda posibilidad de que Gutiérrez de Santa Clara, en su juventud, haya hecho un viaje al Perú en compañía de algún mercader mexicano. Pero tal vez no salió nunca de la Nueva España. Del incipit de su copioso manuscrito se desprende que era "vezino de la gran cibdad de México Thenuchtitlán".

\section{II}

Que fuese hijo de Bernardino de Santa Clara, constaba ya de una indicación de su contemporáneo Dorantes de Carranza ${ }^{26}$, quien, a principios del siglo xvn, menciona entre la progenitura de aquel poblador a un hijo ilegítimo llamado Pedro, todavía vivo en 1603 , es decir cuando Pedro dedica su obra magna al nuevo virrey Marqués de Montesclaros y habla en ella de aquel Santa Clara sin decir que se trata de su propio padre. Puede sospecharse que si metió en el libro V de sus "Quinquenarios" de las Guerras civiles del Perú unos

fray Juan de Zumárraga. En cuanto a los bachilleres, es célebre el bachiller Juan Vélez de Guevara, que fue, hasta la derrota final, capitán pizarrista. Pero ¿Nuño de Castro"? Bien podría resultar de la atribución del nombre de pila de un capitán conocido a un bachiller Juan de Castro, pizarrista ahorcado en 1548. Es típico de nuestro seudocronista atribuir nombres de pila a personajes que no los tienen en las menciones coetáneas, o cambiar audazmente los nombres.

26 Baltasar Dorantes de Carranza, Sumaria relación de las cosas de Nueva España, México, 1902, pp. 169-170. No existiendo este libro en bibliotecas de París, tomamos la referencia del artículo de Robert B. KNox, "Notes on the identity of Pedro Gutiérrez de Santa Clara and some members of his family", RHA, $195^{8}$, núm. 45 , pp. $93^{-105}$. 
19 capítulos (5-23) de historia mexicana, fue, entre otros motivos, para tener ocasión de poner de relieve (cap. 8) la personalidad del hombre cuyo apellido ostenta en segundo lugar, el Bernaldino de Santa Clara que fue consejero de Cortés y "gran amigo" del obispo don fray Juan de Zumárraga. Pedro no dice de él "mi padre" o "mi señor", como diría el Inca Garcilaso, pero termina el capítulo con esta queja de inconfundible acento personal (t. 5, pp. 81-82):

Tuvo en encomienda los pueblos de Atempa, Tezihuytlán y Quatla Hahuaca, y en Guatimala tuvo el pueblo de Ozelotepec, y estos pueblos le dieron por sus trabajos y buenos servicios que hizo al Rey; mas con todo esto se mueren de hambre sus hijos, que viven en grande pobreza y miseria en México, y los bienes y heredades que dejó, el albacea y curador de los menores se alzó con todo ello como si fuera el verdadero heredero.

En otro capítulo del mismo libro (lib. V, cap. 14) encuentra oportunidad para llamar "conquistador" al hombre con cuyos hijos se solidariza, mencionando a un tal "Francisco Hernández del Intornio, sobrino de Bernaldino de Santa Clara, conquistador en la Nueva España" (ibid., p. 132).

Nuestra época, encaprichada con los "complejos", se lanza a imaginar los "complejos del mestizo" del siglo xvi, sin recordar bastante que son a la vez complejos del bastardo. Pero mientras el Inca Garcilaso supera su situación de hijo ilegítimo empleando fórmulas que pueden dar a entender que su madre Chimpu Occllo estuvo casada con el capitán Garcilaso de la Vega, mientras asume idealmente sus dos linajes después de reivindicar - sin éxito- el premio de los servicios paternos y lo que llama audazmente "la restitución patrimonial" de su madre, en cambio nuestro Pedro Gutiérrez se contenta con mencionar la situación de encomendero de que gozó el "conquistador" Bernaldino de Santa Clara, y con lamentar el despojo de que sus hijos fueron víctimas, sin decir abiertamente que era uno de ellos, ilegítimo él y ellos. Baste subrayar dos palabras del título de la obra de Dorantes de Carranza en que se menciona a nuestro Pedro, todavía vivo, como hijo no legítimo de un poblador: "Sumaria relación de las cosas de la Nueva España, con noticia individual de los descendientes legitimos de los conquistadores y primeros pobladores españoles" 27.

Salieron del olvido estos arcanos de la familia del escritor hace quince años, cuando Agustín Millares y J. Ignacio Mantecón (op. eit., t. 2, pp. 158-162) publicaron un resumen y extractos del testamento de Bernaldino de Santa Clara, otorgado en México el 6 de diciembre de 1537. En este documento, Bernaldino se reconoce padre de

27. TORRE Villar, art. cit., p. 213 , recalca con razón esta exclusión implícita de los bastardos. 
ocho hijos -ninguno legítimo- habidos en tres o cuatro mujeres distintas. Una india anónima, ya muerta sin duda, o desaparecida del ámbito doméstico del testador, es la madre de Pedro. Otra india llamada Juliana o Julia, a quien manda dos cargas de "ropa de la de su pueblo", es madre de María y Vicente. Con una española, Teresa Cervantes, ha tenido tres hijas y un hijo, Florentina, Bernardino, Ana e Inés. No se dice quién fue la madre de otra muchacha, Magdalena de Santa Clara, a la que el padre llama "mi hija", mandándole 120,000 maravedís de buena moneda "para que entre monja en Castilla" y otros 10,00o para ayuda de costa del viaje. ¿Sería hija adulterina de una española casada, a quien más valía no nombrar? ¿Sería hija de otra india anónima, ya fallecida? Todo podría ser. Ya que el anciano escritor, en el manuscrito de su Historia, se llamó a sí mismo Pedro Gutiérrez de Santa Clara, vale la pena notar que, de los dos hijos habidos en la india Juliana, la hija, recién casada o desposada con Fernando de Torres (a quien Bernaldino llama su yerno), es nombrada dos veces en el testamento, una como "María Gutiérrez", otra como "María de Santa Clara". El apellido Gutiérrez pudo pasar a los hijos de Bernaldino de Santa Clara debido a relaciones de parentesco o compadrazgo, o de ambos géneros a la vez. Ya aparece en 1512 un Pedro Gutiérrez como consocio de negocios de los hermanos Santa Clara ${ }^{28}$. Un primo de Bernaldino se llamaba Hernán Gutiérrez. En el testamento que nos sirve de fuente única figura un hijo de éste, huérfano menor de edad según parece, llamado Cristóbal Gutiérrez, siendo Bernaldino su tutor y curador de bienes. Con otro sobrino suyo llamado Francisco Rodríguez tenía el testador compañía en la explotación de una recua (de mulas probablemente).

Dos días después de testar, el 8 de diciembre de 1537 , otorga Bernaldino un importante codicilo en el cual anula la declaración de herederos hecha a favor de Teresa Cervantes, de sus hijos Florentina, Bernardino, Ana e Inés, de "Pedro Gutiérrez" y de Vicente, y confirma como heredero universal a Francisco de Villegas, vecino de México. El que el padre no anule entonces las mandas a favor de sus hijas Magdalena y María Gutiérrez significa probablemente que las consideraba como seguras del porvenir, una por su entrada en religión, otra por su casamiento. Los otros seis hijos, aunque fuese bajo la tutela de Teresa Cervantes y de Bartolomé Rodríguez, primo del testador, pudieron parecer al moribundo poco seguros de gozar de su parte de herencia, y pudo ser precaución a favor de ellos el encomendarlos al amigo de confianza designado ya en el primer testa-

28 Francisco del Paso y Troncoso, Epistolatio de Nueva España (15051818), t. 1, México, 1939, p. 25: “...el alcance que fue fecho a Cristóbal de Santa Clara, nuestro tesorero que fue desa dicha isla [Española], e lo que con él e con Bernaldino de Santa Clara su hermano e con Pedro Gutiérrez su compañero he mandado asentar". 
mento como principal testamentario. Francisco de Villegas no dejaría desamparados a las tres niñas y a los tres muchachos... Según Pedro Gutiérrez de Santa Clara, "el albacea y curador de los menores" se apoderó de la totalidad de la herencia...

Todo esto da a pensar que Pedro, al morir su padre, era jurídicamente menor de edad, es decir, menor de 25 años; pero sólo admitiendo que Bernaldino no tendría dos concubinas indias a la vez -hipótesis púdicamente arbitraria- podemos dar por evidente que Pedro nació antes que María (la hija de Juliana), que aparece en el testamento paterno como casada o desposada. Se ha dicho, no sabemos con qué fundamento, que la india madre de Pedro era cubana ${ }^{29}$. Tanto pudo serlo como mexicana o guatemalteca. Lo de india cubana descansa tal vez en el supuesto de que Bernaldino de Santa Clara traería consigo una india criada o manceba cuando vino con Narváez a México, tal vez en la probabilidad de que el futuro historiador de las Guerras civiles, si no mintió, tuviese algo más de 20 años en 1544 al alistarse en el Perú entre los soldados de Pablo de Meneses. Si ponemos en cuarentena, como sospechosísima, la participación personal de Pedro Gutiérrez en la guerra pizarrista narrada por él con técnica engañosamente detallista, quedamos obligados a confesar que carecemos de toda base para fechar su nacimiento en límites cronológicos más estrechos que "entre 1520 y 1530 probablemente".

Acerca del ambiente en que se crió Pedro, los datos reunidos por Serrano y Sanz y B. Knox sobre Bernaldino de Santa Clara permiten pensar que su hogar era uno de los más acomodados de México. Más que "conquistador" era perito en cosas de hacienda y negocios. Hermano del célebre tesorero Cristóbal de Santa Clara, a quien el Comendador de Lares, su protector, tan graciosamente respaldó cuando tuvo que rendir cuentas ${ }^{30}$, Bernaldino es, en Cuba, corresponsal del secretario Francisco de los Cobos, a quien avisa del descubrimiento de Yucatán (D.I.I., t. 11 , pp. 556-559), fuente de posibles mercedes, y figura entre los favorecidos con recomendaciones o con exención de almojarifazgo ${ }^{31}$. Sale como tesorero en la expedición de Narváez, mandada desde Cuba para detener a Hernán Cortés rebelde a la autoridad del gobernador Velázquez. Después de la época de la con-

29 Pedro Henríquez Ureña, Las corrientes literarias en la América hispánica, México, 1949 , p. 215 . SERrano y SANZ en su Introducción a nuestra Historia, p. xiii, opina que "de las tres regiones americanas donde pudo tener su cuna Gutiérrez, la isla Española apenas cuenta probabilidades, algunas más la de Cuba, y muchísimas la Nueva España". Siendo el problema de la "cuna" insoluble sin remedio, sólo cuenta el hecho de que nuestro historiador se sintiese mexicano.

30 Véase el relato encantador del P. Bartolomé de las Casas en su Historia de las Indias, lib. II, cap. 42.

31 Manuel Giménez Fernández, Bartolomé de las Casas, t. 2, Sevilla, 1960, p. 223 . 
quista de la Nueva España, en que se señala como "hombre bien reportado y de mucho consejo" 32 , descuella entre vecinos de Tenuxtitlán México tanto por los cargos municipales que desempeña como por las granjerias en que participa: adquiere solares, cría ganado lanar; tal vez tiene parte en minas de oro, o por lo menos interviene en 1527 para que se reglamente la retribución de los "mineros", capataces cuyas exigencias gravaban enormemente la explotación minera. Su casa es de las que gozan de un caño de agua derivado del acueducto de Chapultepec ${ }^{33}$. Es verosímil la afirmación de Pedro (Hist., t. 5, p. 81) según la cual Álvar Núñez Cabeza de Vaca, al volver de su extraordinaria aventura de diez años a través del continente, se alojó en la casa de Bernaldino de Santa Clara con sus compañeros: sería bastante capaz la vivienda, y el dueño bastante ávido de noticias de los expedicionarios para acogerlos. Uno de ellos era Andrés Dorantes, padre de Bartolomé Dorantes de Carranza, quien, como vimos, menciona hacia 1603 al hijo todavía vivo del dueño de la casa hospitalaria.

Que el obispo Zumárraga fiaba de Bernaldino los mayores intereses consta del acta de posesión del prelado, con fecha de 27 de diciembre de 1533, pues figura en él el hombre de negocios, juntamente con el canónigo provisor del obispado, como apoderado del Obispo; y también del propio testamento tantas veces alegado, donde se lee que Bernaldino fue encargado por el prelado de la administración de los diezmos ${ }^{34}$.

Acerca de la educación de los hijos de Bernaldino tal vez trae el testamento un dato interesante, que no sé si ha sido recogido por los historiadores de la enseñanza en México. Entre los acreedores que menciona para que se les tome juramento de lo que les debe y se les paguen las deudas conforme a lo que montaren según sus libros de contabilidad, figura el maestro de escuela de la calle en que vivía el testador: "un maestro que beza muchachos en la calle de Tacuba". No sabemos si es el mismo "maestro de mostrar a leer a mozos" Gabriel de Castellanos quien, el año anterior, intervenía como testaferro en una operación de compra y venta de solar ${ }^{35}$. Tal vez acudía a él nuestro hombre de negocios para otros menesteres que enseñar a leer a los niños. Es verosímil, nada más, la hipótesis de Serrano y Sanz de que, muerto Bernaldino de Santa Clara, velase el obispo Zumárraga por la educación literaria de Pedro, quien revela en su historia, con gracia algo desaliñada de autodidacto, un modesto bagaje de humanidades.

32 Según F. Cervantes de Salazar, citado por Knox, art. cit., p. 100.

33 Serrano y Sanz, Introducción a nuestra Historia, t. 1, pp. xx-xxvi.

${ }^{34}$ Millares y Mantecón, op. cit., t. 2, p. 161; y, por el acta de posesión, Joaquín García Icazbalceta, Don fray Juan de Zumárraga, ed. R. Aguayo Spencer y A. Castro Leal, t. 3, México, 1947, p. 66.

${ }^{35}$ Millares y Mantecón, t. 2, p. 68, núms. 2015 y 2016. 
Si queremos encaminar las investigaciones biográficas sobre Gutiérrez de Santa Clara hacia un terreno más fecundo que la totalmente estéril búsqueda de su actuación en la guerra civil del Perú, lo más sensato será adoptar como hipótesis que Pedro, terminada su educación, encontró en la Nueva España ancho campo para dedicarse a granjerias semejantes a las que cultivaba Bernaldino en compañía con varios sobrinos y con su yerno, o sea negocios de ganadería: rebaños de yeguas, vacas y ovejas, recuas de bestias de carga. Tal vez fue ésta la manera que tuvo Pedro de "buscar de comer" en la frontera norte de la Nueva España, tierras alejadas de la capital, "pues en ésta no lo tenía”. Estuvo, según le dice al Virrey, "ocupado mucho tiempo en la pacificación de los rebeldes yndios Chichimecos", y llegó a escribir sobre lo que vio en esta guerra unos Coloquios que desgraciadamente se han perdido (Historia, t. 1, p. 11). Pero si allí sirvió a Dios y al Rey "con sus armas y caballos, a su costa", cabe pensar que no fue llevado por una vocación militar, sino por negocios que le "diesen de comer" en aquella zona de expansión minera: la minería de Zacatecas se desarrollaba gracias al azogue importado del Perú. Es natural que esta confesión del escritor al Virrey no adolezca de tanta superchería como la seudoconfesión del "Prohemio al lector", pues la falsa aventura peruana, remota en el tiempo como en el espacio, escapaba fácilmente a la comprobación, mientras los méritos adquiridos por el anciano en la Nueva España, justificación posible de la protección que pide al Marqués de Montes Claros, podrían someterse a una probanza por testigos.

Además, contrastando con la facilidad amplificadora de los episodios peruanos, las páginas del libro $\mathrm{V}$ dedicadas a la situación del Norte de la Nueva España en la segunda mitad del siglo xvı llaman la atención por su densidad y autenticidad. Sobre el asunto no existía ni una sola página impresa. Pero era asunto vital. El virrey don Martín Enríquez mandó hacer siete fuertes, "con guarnición de soldados, en el camino que va desde la ciudad de México a las minas de Zacatecas, para evitar los daños que los Chichimecos hacían a los mercaderes y caminantes que por aquel camino pasaban". Lo cual, vuelto a lo divino, dio materia a Hernán González de Eslava, allá por los años $157^{0}-15^{80}$, para su coloquio sacramental De los Siete Fuertes $^{36}$. Es verosímil que Gutiérrez de Santa Clara hable como testigo de vista de aquella guerra endémica del nuevo distrito minero en que los chichimecos "han muerto muchos españoles, negros y los indios de paz" (Hist., t. 5, p. 239):

36 Fernán GonzÁlez de Eslava, Coloquios espirituales y sacramentales y poesías sagradas, $2^{\mathrm{a}}$ ed., México, 1877 . El coloquio viene como apéndice en el libro de José Rojas Garcldueñas, El teatro de Nueva España en el siglo xvi, México, 1953, pp. 143-157. 
Todos estos españoles iban y venían a sus contrataciones desde la ciudad de México a las minas de los Zacatecas y a otras diversas partes, y estas guerras y rebeliones se movieron en el año de 1549 y turan hasta el día de hoy, que habrá desde el día que esto se escribe más de quarenta años que se comenzaron.

Escribiría esto Pedro Gutiérrez de $159^{\circ}$ en adelante. En vista de su insistencia sobre las matanzas de mulas y bueyes, de caballos, yeguas y vacas, o sea del ganado que utilizaban las víctimas humanas de los salvajes, "mercaderes, arrieros, chirrioneros y carreteros", amén de "los mineros de Zacatecas, Fresnillo, San Martín, Ranchos, Chalchihuites, Santa Bárbara, Indehe" y los de las minas de Buenaventura, es lícito pensar que muy pronto $-y$ ¿quién sabe si antes de 1549?Pedro se dedicó a la ganadería como su padre, su cuñado y sus primos, y llegó temprano a Zacatecas como proveedor de ganado de los mineros. Ésta es, por lo menos, una hipótesis de trabajo que tal vez permita encontrar menciones del futuro seudocronista o de parientes suyos en los archivos de protocolos. Quien lea la importante carta escrita en 1574 por el futuro obispo de México, Moya de Contreras ${ }^{37}$, acerca del estado de peligro mortal en que vivía el Norte minero, a pesar del nuevo auge debido al azogue del Perú, llegará fácilmente a imaginar que los servicios prestados por Pedro en aquella frontera "con sus armas y caballos" fuesen participar en expediciones punitivas y razzias de esclavos contra los indómitos chichimecos, matadores de mulas y caballos. François Chevalier ha mostrado el papel que desempeñó la simbiosis de ganadería y minería en la formación de grandes haciendas por los "hombres ricos y poderosos" del Norte de la Nueva España ${ }^{38}$. El mismo historiador descubrió en un archivo privado de Zacatecas la mención de una merced de estancias de ganado mayor y de caballerías a Joannes de Tolosa y su mujer doña Leonor Cortés ${ }^{39}$. Pues bien, entre las noticias mexicanas y cortesianas

37 Paso y Troncoso, Epistolario, op. cit., t. 11, pp. 176-178. El doctor Moya de Contreras, después de describir la situación en términos a veces idénticos a los empleados por Gutiérrez de Santa Clara, dice (p. 178) : "He entendido de personas de aquella tierra que con sólo darlos a estos indios por esclavos por los días de su vida los prenderán a todos, porque por el interese habrá muchos que se juntarán en camaradas y compañías y lo harán". Bastaría con delimitar la zona en que se pudiesen prender todos, incluso las mujeres y los niños.

38 Nuestra Historia, t. 5, p. 240, menciona el hecho capital para la simbiosis de minería y ganadería en esta región al decir que "estos salteadores les han muerto las mulas y caballos que tenían para el beneficio de los metales de fundición y azogue". Ilustra esta simbiosis François Chevalier en su importante libro sobre La formation des grands domaines au Mexique. Terre et société aux $x v i^{\mathrm{e}} x v i i^{\mathrm{e}}$ siècles, Paris, 1952, pp. 216 ss. (pp. 1 30 ss. de la trad. esp., La formación de los grandes latifundios en México, en: Problemas agricolas e industriales de México, t. 8, núm. 1, 1956).

a9 Chevalier, op. cit., p. 218 , nota 2 de la ed. francesa, y p. 132, nota 53 de la trad. española. 
de Gutiérrez de Santa Clara que proceden de otra fuente que Gómara, figura precisamente la mención de esta hija mestiza del conquistador de la Nueva España. Gómara, después de nombrar a dos hijos naturales de Hernán Cortés, don Martín, mestizo, y "don Luis Cortés, que tuvo en una española", se contentaba con añadir globalmente: "y tres hijas, cada una de su madre y todas indias" 40 . Pedro Gutiérrez de Santa Clara sabía de buena fuente, tal vez por relación personal con una de ellas, que "las hijas naturales fueron llevadas después en España, ecepto doña Leonor Cortés, que casó con Juanes de Tolosa, vecino de las minas de Zacatecas, y tuvieron hijos" (Hist., t. 5 , p. 184 ).

La experiencia mexicana de Pedro Gutiérrez, centrada tal vez en la ganadería de aquel distrito minero, se transparenta también en el capítulo ( 17 ) que dedica al cultivo y provechos del maguey, cuando habla de las púas, cuya punta compara con "una alesna muy aguda o aguja de arriero", de la manera de cocer las pencas "en barbacoas", y de las aplicaciones curativas del zumo de maguey en "arcabuzazos y cuchilladas" o en "encabestraduras de los caballos y mulas”. Nadie, ni Gómara ni el mismo Motolinía, habló tan detalladamente como él de los varios usos de la hilaza de maguey en la cordelería. Después de mencionar las gruesas y largas maromas que "se hacen para tirar las piedras y vigas muy grandes que los indios traen de los montes a la ciudad para que los ciudadanos edifiquen sus casas", añade que

también destas hilazas, torcidas, hacen muchas sogas, cabestros, lazos, jáquimas sueltas, cinchas, calzado de los indios que llaman cacles y arpagates, con otra infinidad de cosas, que los arrieros, chirrioneros y carreteros se sirven destas cosas, y se lleva a muchas y diversas partes a vender... ${ }^{41}$

Bien enterado se muestra Pedro Gutiérrez de los objetos y oficios relacionados con la cría, venta y utilización de ganado mular y caballar, trato de que probablemente vivió en parte, como su padre y sus parientes. Llama también la atención en su obra el mexicanismo engrasado (azogado), que pertenece al léxico de los mineros ${ }^{42}$. Contrasta la seriedad de su información mexicana con su seudo-expe-

40 López de Gómara, Historia de la conquista de México, cap. 251 in fine (ed. J. Ramírez Cabañas, México, 1943, t. 2, p. 298).

${ }_{41}$ Historia, t. 5. pp. 162-167, especialmente p. 165 (las líneas citadas, en que se mencionan objetos y oficios relacionados con la utilización de las mulas). Le gusta imaginar (t. 3, pp. 514-515) cómo en la tierra calurosa de los llanos "no solamente los hombres se despean, mas aun también las bestias... se encalman". Palabras bien típicas de ganaderos.

42 Lo usa (t. 4, p. 505) al describir el temblar de los combatientes antes de la batalla de Huarina ("como si estuvieran engrassados o azogados o muy friolentos"). 
riencia de las cosas peruanas que, cuando se aparta de sus conocidas fuentes impresas, es caprichosa y descarada adulteración.

Además, tratándose de personas (y de personajes no inventados), puede ser que la situación de mexicano de Gutiérrez de Santa Clara explique su más completa información acerca de una figura notable de la guerra pizarrista. Ya hemos dicho que probablemente manejó una copia de la relación de don Alonso de Montemayor, fiel compañero del virrey Blasco Núñez Vela hasta la batalla de Quito. Prisionero de los pizarristas después de esta derrota, deportado por ellos a Chile, se evade en el camino y se refugia en México en la corte del virrey don Antonio de Mendoza. Se ha publicado en colección mexicana ${ }^{43}$ la importante carta de 15 de abril de 1547 en que don Alonso, desde México, informa al Rey de sus servicios, acompañándole la relación de los acontecimientos del Perú. Mientras Cieza de León, el cronista coetáneo mejor informado de las andanzas de don Alonso de Montemayor, no pasa de los primeros informes dados por don Alonso al virrey Mendoza (Guerra de Quito, ed. cit., p. 279a), mientras el presidente Gasca, todavía el 26 de noviembre de 1548 , escribe desde Lima (Co.Do.In., t. 49, p. 45o) que no se sabe "si era ido a España o se quedaba en la Nueva España casado", Gutiérrez de Santa Clara dice terminantemente (Hist., t. 2, p. 406) que "cierto tiempo" después de su llegada a la corte del Virrey,

se casó con una muy noble, virtuosa y hermosa doncella llamada doña Leonor Ponce de León, hija de un caballero vecino de allí y conquistador, llamado Hernán Pérez de Bocanegra, natural de Córdoba, y de doña Beatriz de Chaves su mujer. Hiciéronse grandes fiestas y el Visorrey se halló en ellas con toda la nobleza y caballería de México por los honrar, y después él y todos los demás se vinieron todos acá al Perú a servir Su Majestad y su presidente Pedro de la Gasca cuando vino a recuperar estos reinos, como adelante diremos.

En realidad, don Alonso vino a servir al Presidente algo después, no

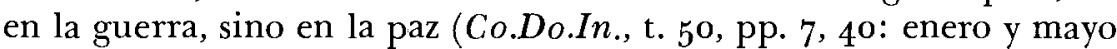
de 1549). Valdría la pena someter a prueba la noticia tan precisa que da Gutiérrez de Santa Clara acerca del casamiento con doña Leonor. A primera vista tiene visos de autenticidad, pues puede suponerse que no se atrevería el seudocronista a fantasear en México a propósito de una familia novohispana tan destacada como la de Hernán Pérez de Bocanegra.

Otro punto curioso en que notamos una posible interferencia de exquisita información libresca con la experiencia mexicana del autor es el nombre del español de la primera expedición de Cristóbal Colón que ve primero las tierras nuevas: "Rodrigo de Terrazas" ["así en vez de Triana", advierte en nota Serrano y Sanz] "vido tierra"

43 Paso y Troncoso, Epistolario, op. cit., t. 5, p. 23. 
(Hist., t. 5, p. $3^{8}$ ). Es casi seguro que esta originalidad de los Quinquenarios procede de Gonzalo de Illescas, cuya Historia pontifical proporcionó a Gutiérrez de Santa Clara algunos "datos" más. Casi seguro también que éste adoptó tan curiosa variante de la tradición unánime por hacerle gracia la homonimia de su paisano Francisco de Terrazas, hijo del que fue alcalde de Tenuxtitlán México en la época de la muerte de Bernaldino de Santa Clara, y autor de un poema sobre Nuevo Mundo y conquista, otra "muestra de una literatura ya formada, aunque naciente" de la Nueva España44.

III

Con cuestiones de esta índole nos vamos acercando al problema que apuntábamos al empezar: el de la vocación y originalidad del novohispano Gutiérrez de Santa Clara como escritor de cosas peruanas. Es de los que nos ayudan a superar el tópico ingenuo de que, entre los "historiadores de Indias", son importantes los que pisaron el suelo del Nuevo Mundo y despreciables los que no salieron de España. Conociendo de vista cada uno de los primeros sólo una parte de los países y acontecimientos de que habla, el valor de unos y otros depende principalmente de la calidad de las relaciones de primera mano que manejaron. Pero es natural que el problema que planteamos aquí no exista para quien siga creyendo como artículo de fe que Gutiérrez de Santa Clara es testigo presencial de la mayor parte de los acontecimientos peruanos de 1544-48 y fidedigno en todo lo que añade a las relaciones y fuentes coetáneas, aunque falte toda prueba documental de su paso por el Perú.

Para los que no se hacen cruces ante la hipótesis de una superchería, es interesantísimo comprender cómo podría un mexicano interesarse por las cosas peruanas, y cómo podría entonces servirle su experiencia de la Nueva España para imaginar y pintar acontecimientos del Perú. Pues en esto se encierra la parte de verdad inherente al tópico que acabamos de criticar. Fijémonos en curiosos detalles inventados por nuestro Pedro Gutiérrez, pues todo lo original es "historia chica" en aquel arte historiográfico dado a la "escena" y la anécdota.

Entre los numerosos personajes que le pertenecen a él sólo, y que probablemente son hijos de su voluntad de crear por imposición de nombres, interesa a los mexicanos el apellido de "Pedro de Arangurel". Surge, en el episodio del prendimiento del Virrey, este vizcaíno fiel, "gran amigo del general Diego Álvarez Cueto y de Geró-

${ }^{44}$ Frase de Torre Villar, art. cit., p. 217, a propósito de Terrazas utilizado por Dorantes de Carranza. Sobre el padre, alcalde ordinario en 1538, hay muchas referencias en Millares y Mantecón, op. cit., t. 2. 
nimo Zurbano, vizcaíno": sube a caballo y galopa al puerto a avisarles (Hist., t. I, pp. 369-364). En Cieza de León, este mensajero vasco se llama Martín de Arauco ${ }^{45}$. La curiosa variación del nombre y del apellido en Gutiérrez de Santa Clara bien podría deberse a un lejano recuerdo de juventud. Bernaldino de Santa Clara, como sabemos, era uno de los hombres de negocios de quienes se fiaba el obispo de México don fray Juan de Zumárraga. Otro de sus hombres de confianza era un vizcaíno llamado Martín de Aranguren, natural de Durango ${ }^{46}$. Tal vez el joven Pedro Gutiérrez pronunciaba "Arangúrel". Con su técnica habitual de reiteración, el escritor utiliza otra vez al imaginario Pedro de Arangúrel como escribano de cabildo en el Cuzco, también, cosa curiosa, al lado de otro vizcaíno, "Machín de Andía", conocido de Cieza como una de las víctimas de Alonso de Toro en el Cuzco ${ }^{47}$. Abundaban los vascos entre los secretarios. Así cobraría consistencia y destino un hijo de la fantasía onomástica de nuestro mexicano.

Ya sabemos que pinta y anima, como cosa vista por él, con personajes dotados de nombre y apellido, una borrachera nocturna de los jefes pizarristas en casa de Carvajal (supra, nota 22). La cosa pasa en Lima durante el otoño de 1544 , antes de empezar la campaña contra el Virrey en el Norte del país de los Incas. En la misma época imagina el seudocronista que, por Navidad, se dan en Lima grandes regocijos públicos, con cañas y "fiesta de moros y cristianos", interrumpiéndose los festejos al recibir Gonzalo Pizarro la noticia de que el Virrey ha sido liberado y ha desembarcado en Túmbez: entonces se prepara a toda prisa la expedición de Bachicao. La veracidad de Gutiérrez de Santa Clara, si la criticamos, tiene que responder ante todo de su cronología, pues en la memoria de un "testigo" del siglo xvi son las fiestas religiosas los puntos de referencias más firmes. Pues bien, las supuestas fiestas limeñas de Navidad de 1544 resultan imposibles del todo, si de veras las interrumpieron para preparar febrilmente la expedición de Bachicao. En efecto, la documentación

45 Guerra de Quito, ed. cit., p. 6ga. "Arauco" también lo llama Lozano, autor de la Relación anónima de la guerra pizarrista utilizada por Zárate y publicada en Lima en 1870 (p. 29, cap. 9). Cf. M. Bataillon, "Un chroniqueur péruvien retrouvé: Rodrigo Lozano", Cahiers de l'Institut des Hautes Études de l'Amérique Latine, núm. 2, Paris, 1961, pp. 5-25. ed. cit.

$46 \mathrm{~J}$. García Icazbalceta, op. cit., passim. Véase el índice del t. 4 de la

47 Historia, t. 2, p. 137. La muerte de Pedro (y no Martín) de Andía en el Cuzco queda bien documentada no sólo por Cieza (op. cit., p. 149b), sino por una carta inédita de los Papeles Pizarro-Gasca (I, fol. 115). Como "Martín de Andía" aparece en una lista de víctimas del terror pizarrista aneja a la relación de don Alonso de Montemayor (extractos en Gonzalo Fernández DE Oviedo, Hist. gen. y nat. de las Indias, lib. 49, cap. 11), es uno de los muchos indicios convergentes de que esta relación fue utilizada por Gutiérrez, quien adopta la forma "Machín". para hacer al personaje más vasco. 
inédita de esta expedición ${ }^{48}$ prueba que la alarma de Lima por el desembarco del Virrey en el Norte sucedería unas seis semanas antes de Navidad. Por Navidad ya estaba Bachicao en Manta, pasado el ecuador, después de haber sembrado el terror en Paita, Túmbez y Guayaquil.

Los pintorescos regocijos de la Navidad limeña, lejos de ser "recuerdos" vividos allí por Gutiérrez, son proliferación literaria de un germen que le dio al mexicano la Historia del Palentino ${ }^{49}$, ella misma elaboración tardía, propensa ya a la óptica anecdótica y novelesca. Sin hablar de Navidad, ni de cañas, ni de moros y cristianos, había recalcado el Palentino la falsa seguridad de Pizarro que "quiso representar el estado y nuevo señorío de su gobernación y mando de la tierra con fiestas y regocijos, y todos sus capitanes y personas de calidad comenzaron a festejarse". Regocijo, dice, que no correspondía al estado de ánimo de muchos, cuyo pesimismo se justificó cuando, por las malas noticias del Norte, "las fiestas se enturbiaron"50. Este enfoque de dramático contraste sugirió a Gutiérrez de Santa Clara tanto la borrachera nocturna de los jefes como los banquetes que se multiplican antes de las fiestas públicas de Navidad, y finalmente estos regocijos públicos. Pero tal vez no se le hubiera ocurrido amenizar su relación con una bonita fiesta de moros y cristianos, de no ser ya antes de $154^{\circ}$ regocijos clásicos en la Nueva España, donde Pedro pudo presenciarlos, y muy sonados, desde la adolescencia ${ }^{51}$. Peruaniza graciosamente el cuadro imaginando que preside la fiesta doña Francisca Pizarro, hija del Marqués: el rey moro, vencido, se quita la corona de papel dorado, coronándose con ella la muchacha

48 Nos referimos, no sólo a una relación inédita del Archivo de Indias (Patronato 185, Ramo 38 ) escrita en Panamá entre el 12 y el 20 de marzo de 1545 , sino a cartas originales de Bachicao y Maldonado (Guanape, 8 dic. 1544) y de Maldonado (Manta, 3 enero 1545) anunciando su llegada a Guanape (poco al sur de Truxillo) el 6 de diciembre, y a Manta (al norte de Guayaquil) Ia víspera de Navidad. Insisten en que tardaron en llegar de Lima a Guanape a causa de las "muchas calmas" (Papeles Pizarro-Gasca, II, fols. 509, 498).

49 Primera parte..., cap. 28 (ed. cit., t. 1, pp. 145-146).

50 Cieza de León, Guerra de Quito, ed. cit., p. 91b, habla también de "muy grandes y costosos juegos y regocijos", pero después de Navidad, y en el capítulo siguiente al que menciona la decisión de mandar a Bachicao contra el Virrey. En este mismo momento, es decir, "después de haber inviado al capitán Hernando Bachicao", es cuando nos dice que Gonzalo Pizarro "estaba a muy gran servicio en la cibdad de los Reyes". Información que, si fue conocida de nuestro seudocronista, pudo sugerirle el personaje del "botiller mayor" (cf. supra, nota 22).

51 Robert Ricard, “Contribution à l'étude des fêtes de moros y cristianos au Mexique", JSA, 24 (1932), 61-63, describe, utilizando a Bernai Díaz del Castillo y a Motolinía, la fiesta organizada en México en $153^{8}$ con ocasión de la Paz de Aigues-Mortes, y la celebrada en Tlaxcala por Corpus Christi de 1539 . El mismo año y por el mismo motivo se celebró otra fiesta de moros y cristianos en Oaxaca (Paso y Troncoso, Epistolario, t. 3, p. 244). 
y encadenando al moro con una cadena de oro fino traído de la provincia de Chile (Historia, t. 2, p. 3o).

Otro rasgo curioso de la seudocrónica de las Guerras civiles que podemos achacar a la experiencia mexicana del autor es la idea fija de que los españoles vencedores en una batalla edificaban una ermita dedicada al santo del día de la victoria. Todos los vecinos de Tenuxtitlán México conocían la ermita de San Hipólito y la fiesta que se celebraba en ella cada año por el aniversario de la victoria definitiva sobre los aztecas ( 13 de agosto de 1521$)^{52}$. Sin embargo nos sorprende leer en Gutiérrez de Santa Clara (t. 2, p. 400), entre las medidas tomadas por Gonzalo Pizarro después de su victoria en los campos de Anaquito, que "proveyó que en aquel mismo lugar se hiciese una ermita, a la cual nombró de Santa Prisca virgen y mártir, porque en tal día se dio la batalla". ¿Se glorificaría de veras en esta forma "la más que civil batalla" maldecida por nuestro seudocronista con palabras tomadas de Juan de Mena? Excusado es decir que Cieza de León en su copiosa y fidedigna relación de la Guerra de Quito ignora este epílogo de la batalla, bien digno de censurarse, si fuera notorio, dentro de la óptica antipizarrista de Cieza.

Hablamos de idea fija de Gutiérrez porque al llegar a la batalla de Huarina (Historia, t. 4, p. 529) se atreve a mencionar otra ermita conmemorativa "que después se hizo en nombre del bienaventurado San Caprassio, que fue a 20 días del mes de octubre, víspera de las Once mil Vírgenes". Es más, en un párrafo retrospectivo sobre la batalla de las Salinas, "que es una legua del Cuzco", dice que allí "está por señal una ermita de San Lázaro, porque se dio la batalla el domingo de Lázaro, a 24 de marzo de 1541 años" 53.

Gutiérrez de Santa Clara, como se ve, trabaja "en serie" sobre las situaciones de victoria, como pinta "en serie" cuadros de batallas y desfiles militares con banderas tendidas. Y esto lleva a afirmar que trabajaba con un almanaque o un Flos sanctorum al alcance de la mano para traer a colación, en cada caso, al santo o santa del día. Pero parece que se deleita en escoger al santo más raro, menos conocido en España. Gómara da como fecha de la batalla de Huarina el día de las Once mil Vírgenes. Otro narrador dice "día de Santa

52 López de Gómara, op. cit., cap. 144 (ed. cit., t. 2, p. 66) menciona la fiesta. Conoce la fiesta y el templo Cervantes de Salazar, México en 1544 . Tres diálogos latinos, reimpr. y trad. de García Icazbalceta, México, 1875, p. 264 .

53 Historia, t. 4, p. 434. En la historia de "los de la entrada" de Diego Rojas, basta que el Palentino (ed. cit., t. 2, pp. 28 y 40) mencione procesiones de los españoles para que nuestro historiador (t. 3, p. 166) puntualice que fueron en procesión "a una hermita que ya tenian hecha, alabando a Dios y a Nuestra Señora y al apóstol Santiago por averies dado tan gran victoria contra estos infieles sin muerte de cristiano ninguno". Pero supone mucha despreocupación (o ironía corrosiva) imaginar ermitas conmemorativas de matanzas entre cristianos. 
Brígida"54. Nuestro Gutiérrez prefiere a San Caprasio obispo de Agen. Otro alarde curioso de erudición hagiográfica ocurre en su relación del martirio del protomártir franciscano de la Nueva Galicia, fray Juan Calero. Hay indicios bastante seguros de que Gutiérrez de Santa Clara manejó en manuscrito la Historia eclesiástica indiana de Mendieta ${ }^{55}$, o unos extractos de ella. Pero se tomó con su fuente arbitrarias libertades. Por lo visto, no le parece bastante atroz la muerte del fraile asaeteado, muerto a macanazos (con que primero le rompen los dientes) y a pedradas. Para hacer el martirio más sensacional y horripilante, cuenta que "le cortaron a pedazos todo el cuerpo, comenzando desde la mano derecha, y luego el pie derecho, y desta manera le hicieron pedazos como lo hicieron a Santiago el Interciso"56. Tal fue, efectivamente, el martirio de Jacobo de Persia, conocido por "el Interciso", 'el cortado en pedazos'.

Asoma no pocas veces en la multiforme superchería del seudocronista su afición a lo horripilante. Tiene un dejo de ironía impasible ante lo macabro en cierto cuento que casi seguramente inventó, tal vez recordando de Mendieta otras muertes en olor de santidad y cuajándolas en torno al apellido de fray Antonio Ortiz leído en la misma fuente, tal vez elaborando rumores referentes al misterioso Gregorio López, el ermitaño que por entonces (1593) había muerto en Santa Fe, en las afueras de México. Cuenta, pues, Gutiérrez de Santa Clara que en el pueblo de Urcos

murió un hombre que se decía Pedro Ortiz, que hacia vida de hermitaño en una sepultura de indios; y fue sacabuche y ministril del gobernador Vaca de Castro. El cual, estando tocando su sacabuche se lo arrebató una bala de tiro grueso de entre las manos y la boca sin le hacer daño ninguno. Escapándose de la cruel batalla de Chupas en donde fue vencido don Diego de Almagro el mozo por el dicho gobernador Cristóbal Vaca de Castro, prometió que dentro de una sepultura de indios serviría a Dios, y así lo cumplió. Dicen que, después de muerto, dende a tres dias le hallaron hincado de rodillas, sin tener mal olor, como si estuviera vivo, y tenía comido el miembro viril, que los indios de aquel pueblo dijeron que un león se lo había comido, que había venido de la sierra, y que ellos le vieron entrar y salir. Tuvo grandes hablas con el ángel de Dios,

54 Fernández de Oviedo, Historia, op. cit., lib. 49, cap. 15, citando la relación de Fernand Mexía.

${ }^{55}$ De ella, o de una fuente común, tomó frases atribuidas a Zumárraga (t. 5 , p. 191; cf. Mendieta, Hist. ecl. ind., libro quinto, cap. 27 y 29 , reimpr. de México, 1945 , t. 4, pp. 80 y $84-85$ ). Gutiérrez completa el versículo bíblico (Ps. 31:6) pronunciado por el Obispo al morir.

56 Historia, t. 5, p. 176. Compárese con la relación más fidedigna de Mendieta, ed. cit., t. 4, pp. 194-195, que probablemente conoció Gutiérrez y alteró caprichosamente, como tantas fuentes de su obra. En este caso manejaría también el Flos sanctorum de Alfonso de Villegas ( $3^{\mathrm{a}}$ parte, Toledo, $15^{89}$, fols. 125 ss., donde se lee la vida y martirio de "Jacobo Interciso"). 
según que después el reverendo padre regente fray Thomás de Sant Martín lo dijo a muchos, el cual le amonestó mirase no fuese el demonio que lo engañaba, que se transformaria en ángel de luz; mas en fin fue hallado hincado de rodillas y llevado al Cuzco a enterrar ${ }^{57}$.

La posible relación de esta extraña flor de santidad con la discutida fama del ermitaño mexicano Gregorio López radicaría en las leyendas que corrían acerca de su personalidad, en los rumores de iluminismo que difundieron en torno a su memoria los alumbrados de Nueva España perseguidos a fines del siglo xvi, y en la denuncia de judaismo secreto que contra el solitario de Santa Fe profirió Luis de Carvajal el Mozo, procesado por judaizante ${ }^{58}$. Lo del miembro viril misteriosamente comido ¿sería reminiscencia de la posible circuncisión oculta?

Si alguien juzga desatinado atribuir al desmañado Gutiérrez de Santa Clara tanta maña, tanta ironía disimulada entre las líneas de un breve cuento hagiográfico, tal vez cambie de opinión después de fijarse en los dos ejemplares que nos ofrece del portugués a quien entierran "vestido como estaba". El primero es un arcabucero de Francisco de Carvajal, uno de los 200 y tantos personajes sólo conocidos del seudocronista, quien lo bautiza Pedro Galván. Nos cuenta que, en la noche de Pocona, hiere mortalmente a este infeliz portugués el famoso balazo que sólo hirió a Carvajal de soslayo en una nalga cuando algunos pizarristas quisieron matar a su jefe temido y odiado ${ }^{59}$ : según Gutiérrez de Santa Clara, única "fuente" de tan

57 Historia, t. 3, pp. 42-43. Pudo inspirarse el autor en el epílogo del martirio de fray Juan Calero (Mendieta, ed. cit., t. 4, p. 195), en que se descubre intacto el cadáver del fraile en medio de los cuerpos de sus compañeros indios comidos de adives o lobos o de aves carniceras: "se tuvo por milagro que el cuerpo de este santo no estuviese comido, y juntamente con esto, que a cabo de cinco días no tuviese alguna corrupción o mal olor, siendo tiempo de calores" (cf. ibid., p. 219 , la conservación milagrosa del cuerpo de fray Juan de Herrera muerto por los salvajes chichimecos).

58 Julio Jiménez Rueda, Herejias y supersticiones en la Nueva España, México, 1946, pp. $145,146,148,15^{1}$ y 155 para los procesos de alumbrados. Y para la implicación del ermitaño de Santa Fe en el proceso de los Carvajales judaizantes, Alfonso Toro, La familia Carvajal, México, 1944, t. 2, pp. 186-192. No conozco otra biografía moderna del ermitaño que la de FERnando Ocaranza Gregorio López, el hombre celestial, México, 1944 (colección Vidas mexicanas, núm. 14).

59 "Famoso" balazo decimos, sin atrevernos a decir "histórico". No lo menciona Cieza de León, el cronista mejor informado de esta guerra, aunque dice que Carvajal había sido avisado de que "los suyos conjuraban de le matar" y que durante la noche de Pocona "andaba disfrazado... por el miedo que tenía a los suyos no le matasen". [Lozano], Relación [anónima], ed. cit., p. 96, dice que el propio secretario de Carvajal, su hombre de confianza Pedro de Avendaño, "tomó un arcabucero con quien tenía concertado el negocio e amostrándole al capitán Carvajal le tiró y le dio en una nalga" (ZÁrate, Hist. 
curioso "dato", la bala, por un capricho del destino inverso del que salvó la vida al sacabuche ${ }^{60}$, dio después de lleno en la espalda del arcabucero portugués. Como los gritos del moribundo podían desmoralizar a los compañeros, le quitaron de allí. Intentó vanamente el médico curar al herido, quien "dende a un rato murió y otro día fue enterrado por sus amigos, asi vestido como estaba" (t. 3, p. 259). El último pormenor, a primera vista, es mera contingencia de esas "que no se inventan", según la mejor tradición del cuento "realista" (o, como dice Diderot, "histórico"), y dan a tales cuentos su sabor de verdad.

Pero nos espera otro cuento de portugués, el de la muerte del

del Perú, $B A E$, t. 26 , p. $543^{b}$, retocando esta fuente, que sigue de muy cerca: ".. le hizo tirar y le dio en soslayo en una nalga"). El Palentino (Hist., ed. cit., t. 2, p. 52) menciona la herida "en un muslo", y más tarde (p. 62) cuenta cómo Carvajal se enteró de que el autor del arcabuzazo era un tal Matamoros, a quien mandó ahorcar, aunque "jamás mostró haber entendido que Matamoros le había herido". Gutiérrez de Santa Clara refunde y amplía a su sabor, con mucha vida, la versión del Palentino, ya novelesca, contaminándola con la de Zárate.

60 Otra muestra de la ironía de Gutiérrez de Santa Clara frente a las su puestas ironías del destino: Cuando entró en Lima el ejército de Pizarro, "ivan todos los soldados disparando los arcabuzes por el ayre, uno de los quales tiró a una ventana de la casa del capitán Diego de Agüero y mató a un cazique y señor indio del pueblo del dicho Agüero que estava junto a un frayle mercenario, los quales se avian allí puesto por ver cómo entraban los capitanes y soldados pizarristas. Algunos dixeron que le fue mandado que matasse al frayle y no al cazique indio; si ello fue assi, cierto fue gran maldad en querer matar a un religioso, y en lo de la muerte del indio, no se habló dello ni se dixo cosa alguna, ni los oydores ni la justicia del pueblo no hizieron pesquisa de quién lo mató ni quién lo mandó matar, porque no se atrevieron, antes se dissimuló con dezir que fue caso fortuito y sin pensallo" (Historia, t. 1, p. 464). Original desarrollo de una versión inédita utilizada sin duda por Gómara y por nuestro seudocronista, según la cual fue capricho perfectamente intencional y sin sorpresa la muerte del indio: "estaba en la ventana mirando un indio de Diego Agüero, y ciertos españoles junto a él, y un soldado de los arcabuceros... asestó con el arcabuz al indio diciendo: ique le acierto!, y disparando dio con el indio muerto en tierra. Assi diz que andan tan encarnizados en matar a hombres que no hazen diferencia dellos a bestias. Y en estar allí los oidores y no hablar en ello, ni ser parte para cosa de justicia, se nota mucho [y] se desautoriza la justicia, de que tan huérfana queda la tierra" (Relación publicada del original entonces conservado en Simancas por el capitán LUCAs DE TORRE en su edición del Palentino, ed. cit., t. 1, Apéndice Iv, p. 340). Puede ser otra original utilización de esta relación (anónima) lo que dice Gómara (Historia, ed. BAE, t. 22, p. $25^{8 a}$ ) a propósito del suplicio del capitán Gumiel: "Paresce que había hablado libremente contra el Gobernador [Pizarro] y Maestro de Campo [Carvajal] y reprehendido" al tal soldado matador. -La misma relación anónima menciona (p. 344) otra herida análoga, pero fortuita, de un vecino de Panamá que miraba desde una ventana la entrada de Bachicao (cf. Gómara, Historia, ed. cit., p. 259b). Gutiérrez de Santa Clara (Historia, t. 2, p. 93) recoge también el hecho de la misma fuente, imaginando la agravante de que el herido "estaba enfermo" y "después estuvo a canto de morir" por la herida. 
padre Pantaleón, mencionado por las fuentes más fidedignas como una de las víctimas de la crueldad de Francisco de Carvajal. Su historia viene contada casi en la misma forma por Lozano (y su plagiario Zárate) y por el Palentino (el único de los tres que da a ese "clérigo de misa" por portugués) ${ }^{61}$.

Lo capturan los pizarristas cuando cumplía una misión secreta entre los leales del alto Perú y los de Lima: lo ahorcan los rebeldes colgándole del cuello unas escribanías (o unas cartas) y un breviario, emblema infamante del mensajero sacerdote. Gutiérrez de Santa Clara, como era de esperar, "sabe" el apellido, bien portugués por cierto, del padre Pantaleón. . de Aguiar. Da al episodio un desarrollo completamente original, que insiste mucho en la indumentaria del clérigo disfrazado para escapar a la vigilancia del enemigo: "traía un sayo negro, y una almilla de grana y una capa negra, la barba crecida y larga de un palmo, un bonete colorado y un sombrero grande, una espada con una daga en la cinta, un broquelete acerado y una cota de malla". Cuando la víctima discute con el verdugo, queriendo escudarse con su fuero eclesiástico, Carvajal, aludiendo al disfraz, dice con sorna cruel: "Mirad que yo no mando ahorcar a ningún clérigo, sino a un rufián desuellacaras, de los de Sevilla"'e2. $\mathrm{Y}$ es cierto que, con esta irónica disculpa, Carvajal templa más bien la falta de respeto con que ahorca sistemáticamente a los sacerdotes espías o mensajeros de los leales. A manera de epílogo semi-devoto, Gonzalo Pizarro, al llegar y al ver ahorcado a Pantaleón "de Aguiar", "hizo muestra que le pesaba dello y prestamente lo mandó quitar de allí y enterrar vestido como estaba y mandó al padre Márquez que le dijese una misa..."

Confieso que no entendí primero por qué tanto el arcabucero

${ }^{61}$ [LozANo] autor de la Relación..., ed. cit., p. 159; Zárate, ed. cit., p. $56_{4} b$; Palentino, ed. cit., t. 2, p. $3^{61}$. -Gómara, ed. cit., p. $269 a$, habla sin más de "un sacerdote" tomado y ahorcado por Carvajal. No es nada inverosimil el detalle de "las cartas y el breviario al cuello", pues Lucas Martínez Vegaso, desde Arequipa (12 de abril de 1547), cuenta con humorismo macabro cómo manda prender y castigar a los traidores, incluso a los "que traen perdón de su señoría", contentándose con "ahorcalles con los perdones al cuello" en vez de "hacerlos cuartos" como a los demás (Papeles Pizarro-Gasca, I, fol. 795).

${ }^{62}$ Historia, t. 4, pp. 482-483. Esta versión puede inspirarse en algún documento coetáneo que tenía en cuenta la información hecha por Alonso de Villacorta en nombre de Gonzalo Pizarro para disculparse ante el obispo del Cuzco de la muerte de un sacerdote (lo llaman sin más "el padre Pantaleón clérigo"). La pregunta octava es: “...si saben que el padre Pantaleón fue tomado en ábito de lego con una capa negra con capilla y una espada, y que no traía tonsura, y que avía traído despachos de Lorenzo de Aldana y del regente de Lima y bolvía con otros despachos del capitán Diego Centeno y con muchas cartas de muchas personas, y que traía inquietada su persona y conciencia andando de noche y de dia por caminos, y que no rezava sus oraciones ni tenía breviarios en que los rezase por andar mezclado en negocios seculares proibidos en derecho a tales sacerdotes" (Papeles Pizarro-Gasca, I, fols. 566-567). 
de Pocona como el sacerdote disfrazado había sido enterrados vest $i$ dos como estaban, y pensé que en el segundo caso era mera insistencia en el traje tan impropio de un sacerdote. Pero por una feliz casualidad leí pocos días después un cuento de la Picara Justina con la anotación marginal del autor: "Portugués, muere vestido y por qué”. Allí trae a colación Justina la historieta, claramente folklórica:

del otro portugués que se vistió para morir, y dijo: "Ahora máteme Deus, con condeçaon que el dia do juizio no me tire este vestido o truque, que eo quiero que co o meo me faga Deus bem"'63.

Es decir que según el folklore de los castellanos, rico en pullas contra sus vecinos, el vanidoso portugués quería morir y enterrarse no humildemente amortajado, sino con el traje mejor, para que Dios, el dia del Juicio, le tratase según los méritos... de su traje.

No dudemos de que Gutiérrez de Santa Clara condenó al padre Pantaleón a ser ahorcado y enterrado con vistoso traje, porque lo daba el Palentino como portugués, y porque le divertía secretamente el chascarrillo.

¿Qué cuentas tenía que ajustar el mexicano Gutiérrez con los portugueses? ¿Por qué fantaseó a un portugués más en la persona del ostentoso "Francisco de Melo", pizarrista vecino del Cuzco, el cual, según el seudocronista, hizo pintar en su casa unos frescos -unos murales, dirían los mexicanos de hoy-con alegorías de las guerras civiles del Perú hasta la más candente actualidad, apareciendo Gonzalo Pizarro encima de la rueda de Fortuna, "armado de todas armas y caballero en un furioso caballo y una lanza en la mano" $?^{64}$ Nunca entenderemos bien la originalidad historiográfica de Pedro Gutiérrez de Santa Clara mientras nos empeñemos en admitir ciegamente que todos sus "datos" originales son fruto de una

63 Francisco López de Úbeda, La picara Justina (1605), ed. J. Puyol, Biblióf. Madrileños, Madrid, 1912 , t. 2, p. $26_{5}$ (lib. IV, cap. 2).

64 Historia, t. 3, pp. 411-413. Esta invención es del mismo estilo que la de la crónica versificada del pirata Bachicao. Con su constante técnica de repetición de nombres, preparó Gutiérrez de Santa Clara (ibid., pp. 94 y 10o) esta curiosa revelación sobre la casa de Francisco de Melo, nombrando primero al personaje como "thesorero de Su Magestad" elegido alcalde ordinario durante la brevisima ausencia del Cuzco del teniente pizarrista Alonso de Toro, y perdonado al volver éste a ruego del obispo Solano. Hechos ignorados (como el mismo personaje) de las fuentes fidedignas, que sólo conocen a un Garcia de Melo tesorero, vecino del Cuzco, en fecha más tardía (1566 según Doc. inéd. de Ultramar, t. 15, pp. 271, 275), tal vez el mismo García de Melo mencionado por Cieza de León (Guerra de Chupas, Co.Do.In., t. 76, p. 278) como gravemente herido en la batalla de Chupas, y mencionado entre los titulares de repartimientos del Cuzco hacia 1548 (R. Loredo, art. cit., p. 314). Era conocidamente portugués el apellido Melo. Es curioso que haya sido escogido por el continuador anónimo del Lazarillo de Tormes (Amberes, 1555) para el hermano de Licio capitán de los atunes, "también muy ahidalgado atún". 
experiencia de cuatro años vivida en el Perú, o son adiciones arbitrarias sin más intención común que superar en información a los clásicos historiadores de los mismos sucesos, Gómara, Zárate y el Palentino. En realidad muchos de estos datos se derivan (con más o menos libertad) de una documentación manuscrita; muchos cuadros, personajillos, incidentes o peripecias nacen del propósito, que finalmente logró Gutiérrez, de crear la sensación de lo vivido. En esta creación manifiesta un estilo prolijo y detallista que de cuando en cuando imita el de la epopeya al evocar el estruendo bélico ${ }^{65}$, pero con mayor frecuencia insiste en aspectos o preocupaciones al margen de la violencia guerrera: avituallamientos, precio de las cosas, papel de las mujeres, fiestas, elementos que podríamos resumir como de "paz en la guerra". Dijo Rafael Loredo que tenía "memoria de mercader". Nosotros sugerimos que se rectifique "imaginación de mercader". Muchos detalles de la historiografía peruana tal vez tengan una raíz mexicana en su experiencia de hombre de negocios, que esperamos pueda rastrearse gracias a investigaciones en los archivos de México (D. F.) y de Zacatecas.

No hagamos mucho hincapié en la cuestión de cómo llegarían a sus manos unos papeles inéditos acerca de los acontecimientos del Perú de 1544-48. Circulaban entonces mucho más de lo que hoy imaginamos las relaciones oficiales de sucesos de actualidad. El propio presidente Gasea, al explicar cómo faltaban en el Consejo de Indias algunos de sus informes, dice ${ }^{66}$ que "los de aquel consejo [los] havían dado a personas particulares, como se suele hazer en las cosas de nuevas, especialmente quando son de cosas que todos desean saber". Algún personaje eclesiástico o seglar pudo muy bien traer de España a México copias de documentos referentes a la guerra pizarrista $^{67}$; y en la misma capital de la Nueva España se escribió

65 Véase el movimiento heredado de los cantares de gesta en los relatos de las batallas de Quito (t. 2, p. 381: “...alli pudiérades ver la matanza que los unos a los otros se hazían, que sin ninguna piedad se herían a manteniente como mortales enemigos, de manera que alli veriades muchos y diversos géneros de muertes...") y de Huarina (t. 4, p. 516: “...alli pudiérades ver mortales golpes y bravas heridas que los unos y los otros se daban con las lanças, espadas y con hachas de armas"..., etc.).

66 Carta inédita de Gasca a Guillermo Van Male, de Palencia, 23 de agosto 1553 (Papeles Pizarro-Gasca, II, fol. $27^{8} \mathrm{r}^{\circ}$ ).

${ }_{67}$ También pudo haber colaboradores de Gasea que, al regresar del Perú, se quedasen en la Nueva España y guardasen documentos de la guerra pizarrista. No sería el caso de cierto "capitán Francisco González de Valdecañas" que, después de muerto Gasea, escribió al Rey pidiendo el premio de grandes servicios, al parecer imaginarios, que se jactaba de haber prestado al Presidente en su obra de pacificación del Perú (Paso y Troncoso, Epistolario, t. Io, núm. 579, pp. 162-167). Se trata de un personaje tan desconocido en los relatos y en la documentación de la guerra pizarrista como nuestro Gutiérrez de Santa Clara. No figura en la lista de 245 personas beneméritas entre las cuales el Presidente repartió 135,000 pesos de renta porque "le ayudaron a pacificar el Perú". La 
-tal vez se difundió algo- la relación de don Alonso de Montemayor sobre los acontecimientos de esta guerra anteriores a 1547 .

El verdadero problema planteado por la Historia de Pedro Gutiérrez de Santa Clara es el de saber cuándo y cómo se encariñó el autor con tan atractiva materia hasta el punto de formarse un aparejo de historiador del Perú. Lo cierto es que se documentó no sólo sobre la guerra pizarrista, sino sobre el Perú de los Incas y la historia natural y moral del país; y la información de que disponía despertó en él la ambición de superar las historias ya publicadas aunque fuese a costa de un esfuerzo imaginativo y de curiosas supercherías. Aun en el caso -improbabilísimo- de que anduviese por el Perú en su juventud, la vis a tergo de este pasado no bastaría para explicar tan curiosa vocación de escritor, manifestada en la vejez y tan profusamente nutrida de literatura preexistente. Siendo tan poco convincente la experiencia peruana personal que alega para disfrazar su reelaboración de lo leído, lo mismo da que recuerde un tiempo vivido directamente por él o lo que oyó acerca de lo que vivieron mercaderes mexicanos del tipo de Pedro del Golfo durante la guerra pizarrista. Eran legión los auténticos soldados que no escribían nunca sus recuerdos -a lo sumo exponían sus servicios para pedir mercedes en recompensa-, y menos aún se convertían en cronistas o seudocronistas. El caso de Gutiérrez de Santa Clara requiere análisis literario, psicológico y social.

Se nota a primera vista en él un realismo prosaico inclinado a contar los palos y los dineros, a imaginar en detalle lo que come y viste la gente; le interesan los móviles interesados o sentimentales de las acciones humanas; también gasta bastante ironía en imaginar caprichos de la fortuna que salvan o matan a los individuos para que luzca mejor el destino de la historia. En efecto, se divierte muchas veces en inventar peripecias o maquinaciones que traen al lector suspenso sin cambiar aquel destino, pues siempre llegan a empalmar con el curso documentado de los hechos históricos. Lo mejor que escribe es a modo de estampas o miniaturas que ilustran páginas de historia conocida. ¿Cómo nos gustaría conocer, con su idiosincrasia personal, el contexto social en que acometió su empresa! Desde luego, escribir una obra amplia y amena de historia del Perú, centrada sobre la rebelión pizarrista que acabó con el triunfo del poder real, podía ser tenido en "servicio" por un Virrey de la Nueva España, en una época en que pasar de México a Lima era

lista (R. Lonedo, Los repartos, Lima, 1958, pp. 352-361) abarca desde las personas más destacadas hasta personajes humildes como (p. 356) "Sanctos, cerragero" y un "Gutiérrez arcabuzero" que no hay motivo serio para identificar con el seudocronista. La carta del desconocido capitán (México, 26 de enero de 1567) hace sospechar si sería una forma fácil de estafa, en la Nueva España, el pedir premio por méritos adquiridos en el Perú. Nuestro Pedro, por lo menos, no llevó a tal extremo su superchería literaria. 
el ascenso normal de los virreyes: fue el caso de los dos magnates que, uno hacia 1595 , otro hacia 1603 , fueron obsequiados por Gutiérrez de Santa Clara con la dedicatoria de su obra. Pero ¿por qué la escribiría tan tarde, disculpando sus imperfecciones con su poca cultura de autodidacto, con el "no nacer en España", con "la priesa del escribir" y con la "cansada vejez" que le hacía temblar las manos (Hist., t. 6, pp. 304-305)? ¿Buscaría el consuelo de la literatura y el favor de los virreyes después de retirarse de los negocios? Nos sugiere él mismo una explicación de esta índole al decir que no pudo "acabar" su obra antes por haber tenido que ir "a buscar de comer" lejos de México ${ }^{68}$.

Debo formular una sugerencia más, que hasta ahora no me fue dado poner a prueba mediante investigaciones en fondos mexicanos de Inquisición. Gutiérrez de Santa Clara pertenecía no sólo al mundo de los mestizos, sino al de los cristianos nuevos de la Nueva España. Que fuese "conversa" la familia paterna de Pedro, lo consideró Serrano y Sanz como probado por muchos documentos ${ }^{69}$. No hay que dar mucha importancia a las citas bíblicas (casi todas vulgares) que adornan su epístola dedicatoria al Virrey, ni al tono quejumbroso de nuestro autor, que teme ser víctima de su atrevimiento y de la malevolencia ${ }^{70}$. Sin embargo, no se puede descartar la posibilidad de que su regreso a Tenuxtitlán México después de largos años de negocios y correrías en la zona minera de Zacatecas guarde relación con un gran drama de los cristianos nuevos en el Norte del Virreinato. Me refiero a los procesos por judaismo contra la familia Carvajal $^{71}$. Trabajar sobre tal hipótesis, sin más base que la ascendencia de cristianos nuevos de la familia Santa Clara, requiere natural-

68 Historia, t. 1, p. 10. Es lícito suponer que esta epístola dedicatoria al nuevo virrey don Juan de Mendoza y Luna, Marqués de Montesclaros, escrita en 1603 para celebrar "su buena venida", es refundición de otra casi igual que el autor dirigiría a su antecesor don Gaspar de Zúñiga y Acevedo, como el colofón en latín que se lee al final de la obra (t. 6, p. 323; don Gaspar era virrey de la Nueva España desde 1595 cuando salió en 1603 para el Perú; allá también había de ir destinado don Juan en 1606 ).

69 Historia, Introducción al t. 6, pp. xix-xx. Cf. SERrano y Sanz, Origenes de la dominación española en América (NBAE, t. 25, Madrid, 1918), p. li. En el Libro verde de Aragón, ed. Isidro de las Cagigas, Madrid, 1929, aparece una Clara de Santa Clara "herética judía relaxada [en] sus huesos" en 1495 (p. 116) y un Jerónimo de Santa Clara entre los "confesos condenados a fuego" en 1495 (p. 143).

70 Historia, t. 1, p. 10, y t. 6, p. 301. Para esto, como para sus acrósticos finales, se inspira visiblemente Gutiérrez de Santa Clara en la gran tradición prologal de la Celestina (cf. M. Batalllon, "La Célestine" selon Fernando de Rojas, Paris, 1961, pp. 209-212).

71 Cf. A. Toro, op. cit., y la documentación inquisitorial en los tomos 20 y 28 de las "Publicaciones del Archivo General de la Nación": Los judios en la Nueva España, México, 1932, y Proceso de Luis de Carvajal el Mozo, México, 1935 . 
mente tanta prudencia como espíritu crítico. Pero en tal contexto histórico, no deja de llamar la atención la fraseología usada por nuestro Pedro Gutiérrez al final del cap. 59 de su quinto y último libro (Hist., t. 6, p. 263). No se contenta con expresar el clásico miedo del escritor frente a posibles detractores: "aunque en medio del camino no faltaron, como suele acontecer en tales obras, grandes estropiezos, embueltos con muchos recelos y grandes temores que los detractores me pusieron por delante". Como si no bastase acogerse a la protección de un Virrey, se somete a la corrección de la ortodoxia: "me pongo y someto debajo de la corrección y gremio de la Santa Madre Iglesia y a la sombra de tan buen árbol". Precaución no usual en libros de historia.

No era necesario que tocase personalmente a Pedro Gutiérrez de Santa Clara la persecución contra los cristianos nuevos judaizantes para que, con la creciente preocupación genealógica, corriesen chismes sobre la falta de limpieza de su familia. También pudo, sin llegar a incurrir en sospecha de judaismo, zozobrar económicamente a consecuencia de negocios con los Carvajales, cuyos procesos empezaron en ${ }^{1589}$. Luis de Carvajal el Viejo, nombrado gobernador de Nuevo León, había sido considerado por el virrey Martín Enríquez como hombre capaz de pacificar a los chichimecos y "tratarlos de paz" en vez de "beberles la sangre" ${ }^{2}$. Su sobrino Luis de Carvajal el Mozo, cuyo proceso fue tan sonado, tuvo negocios en Zacatecas, y hay quien supone que tal vez "fuera a comerciar con sal y esclavos que llevaría del Nuevo Reino de León, ya que tales mercancías hallaban gran demanda en los reales de minas"7.3. También pudo Pedro Gutiérrez no tener trato con ellos y observar calladamente, o hasta con vaga complacencia, la persecución contra la nueva oleada de pobladores judaizantes que venían a perturbar la paz de que gozaban los descendientes de los primeros conversos venidos a América. De todos modos, un hecho social de tanta importancia pudo despertar la atención de nuestro autor hacia los portugueses. Es conocidísimo el hecho de que los cristianos nuevos denunciados por judaizantes en la Nueva España eran portugueses en su mayoría como lo era la misma familia Carvajal. Esto pudo dar nueva popularidad local a algunos chistes antilusitanos importados de Castilla. Allá en la lejana España, los portugueses de la tradición popular eran el pueblo del reino vecino, orgulloso, independiente durante siglos, ahora reunido a la corona de Felipe II. En la Nueva España eran los intrusos sospechosos de judaísmo. Por eso no resultaría raro que cuentos de portugueses enterrados con su vestido -evocan-

72 A. Toro, op. cit., t. 1, p. 41. Cita de un informe del Virrey dirigido a su sucesor, publicado por J. T. MEDina en su Historia del tribunal del Santo Oficio de la Inquisición en México, Santiago de Chile, 1905.

${ }^{73}$ A. Тово, op. cit., t. 1, pp. $125^{-126 .}$ 
do tal vez esta pulla otro traje (el sambenito) que no se enterraba con el dueño-, o un cuento de ermitaño con el miembro viril misteriosamente comido, tuviesen peculiar resonancia en México cuando se ventilaban los procesos de la familia Carvajal y se hacía la denuncia póstuma contra Gregorio López.

Conste que con tales suposiciones no pretendemos despejar de golpe las incógnitas de la vida de Gutiérrez de Santa Clara, de sus negocios, de su mentalidad y de su vocación de escritor. El propósito de estas páginas es incitar a los mexicanos de hoy a darse cuenta de que este escritor es problema mexicano, y a tratarlo como figura original de las letras novohispanas de fines del siglo xvi.

Marcel Bataillon

Collège de France. 